\title{
Increased migration of olfactory ensheathing cells secreting the Nogo receptor ectodomain over inhibitory substrates and lesioned spinal cord
}

\author{
Diego Reginensi - Patricia Carulla $\cdot$ Sara Nocentini $\cdot$ Oscar Seira $\cdot$ \\ Xavier Serra-Picamal · Abel Torres-Espín • Andreu Matamoros-Angles • \\ Rosalina Gavín • María Teresa Moreno-Flores · Francisco Wandosell • \\ Josep Samitier · Xavier Trepat $\cdot$ Xavier Navarro $\cdot$ José Antonio del Río
}

Received: 18 November 2014/Revised: 6 February 2015/Accepted: 17 February 2015/Published online: 24 February 2015

(C) Springer Basel 2015

\begin{abstract}
Olfactory ensheathing cell (OEC) transplantation emerged some years ago as a promising therapeutic strategy to repair injured spinal cord. However, inhibitory molecules are present for long periods of time in lesioned spinal cord, inhibiting both OEC migration and axonal regrowth. Two families of these molecules, chondroitin sulphate proteoglycans (CSPG) and myelin-derived inhibitors (MAIs), are able to trigger inhibitory responses in lesioned axons. Mounting evidence suggests that OEC migration is inhibited by myelin. Here we demonstrate that OEC migration is largely inhibited by CSPGs and that inhibition can be overcome by the bacterial enzyme Chondroitinase $\mathrm{ABC}$. In parallel, we have generated a
\end{abstract}

Electronic supplementary material The online version of this article (doi:10.1007/s00018-015-1869-3) contains supplementary material, which is available to authorized users.

D. Reginensi · P. Carulla $\cdot$ S. Nocentini · O. Seira

A. Matamoros-Angles · R. Gavín · J. A. del Río $(\bowtie)$

Molecular and Cellular Neurobiotechnology, Institute of

Bioengineering of Catalonia (IBEC), Parc Científic de

Barcelona, Baldiri Reixac 15-12, 08028 Barcelona, Spain

e-mail: jadelrio@ibecbarcelona.eu; jadelrio@ub.edu

D. Reginensi - P. Carulla $\cdot$ S. Nocentini $\cdot$ O. Seira

A. Matamoros-Angles · R. Gavín · J. A. del Río

Department of Cell Biology, Universitat de Barcelona,

Barcelona, Spain

D. Reginensi $\cdot$ P. Carulla $\cdot$ S. Nocentini $\cdot$ O. Seira

A. Matamoros-Angles · R. Gavín · J. A. del Río

Centro de Investigación Biomédica en Red sobre Enfermedades

Neurodegenerativas (CIBERNED), Barcelona, Spain

O. Seira

Blusson Spinal Cord Centre and Department of Zoology, Faculty of Science, International Collaboration On Repair Discoveries (ICORD), University of British Columbia, Vancouver, Canada stable OEC cell line overexpressing the Nogo receptor $(\mathrm{NgR})$ ectodomain to reduce MAI-associated inhibition in vitro and in vivo. Results indicate that engineered cells migrate longer distances than unmodified OECs over myelin or oligodendrocyte-myelin glycoprotein (OMgp)coated substrates. In addition, they also show improved migration in lesioned spinal cord. Our results provide new insights toward the improvement of the mechanisms of action and optimization of OEC-based cell therapy for spinal cord lesion.

Keywords Olfactory ensheathing cells · Traction force microscopy $\cdot$ Chondroitin sulphate proteoglycans . Cell migration $\cdot$ Nogo receptor ectodomain
X. Serra-Picamal
Integrative cell and tissue dynamics, Institute for Bioengineering of Catalonia, 08028 Barcelona, Spain

A. Torres-Espín · X. Navarro

Department of Cell Biology, Physiology and Immunology, Institute of Neurosciences, Edif. M, Universitat Autònoma de Barcelona, Bellaterra 08193, Spain

A. Torres-Espín · X. Navarro

Grupo de Neurobiología, Instituto de Investigaciones

Biosanitarias, Facultad de Ciencias Biosanitarias, Universidad

Francisco de Vitoria, Pozuelo de Alarcón 28223, Madrid, Spain

M. T. Moreno-Flores

Centro de Biología Molecular 'Severo Ochoa', Universidad Autónoma de Madrid (CBM-UAM), Madrid, Spain

F. Wandosell

Centro de Investigación Biomédica en Red de Enfermedades Neurodegenerativas (CIBERNED), CBM-UAM, Madrid, Spain 


$\begin{array}{ll}\text { Abbreviations } \\ \text { CGN } & \text { Cerebellar granule neurons } \\ \text { ChABC } & \text { Chondroitinase ABC } \\ \text { CNS } & \text { Central nervous system } \\ \text { CSPG } & \text { Chondroitin sulphate proteoglycan } \\ \text { eGFP } & \text { Enhanced green fluorescence protein } \\ \text { FTTM } & \text { Fourier transform traction microscopy } \\ \text { GDNF } & \text { Glial-derived neurotrophic factor } \\ \text { GFAP } & \text { Glial fibrillary acidic protein } \\ \text { HRP } & \text { Horseradish peroxidase } \\ \text { MAIs } & \text { Myelin-derived molecules } \\ \text { NgR } & \text { Nogo receptor } \\ \text { OEC } & \text { Olfactory ensheathing cell } \\ \text { OMgp } & \text { Oligodendrocyte-myelin glycoprotein } \\ \text { SCI } & \text { Spinal cord injury } \\ \text { TFM } & \text { Traction force microscopy } \\ \text { TUJ-1 } & \text { B3-Tubulin }\end{array}$

\section{Introduction}

Spontaneous regeneration of damaged axons in the lesioned spinal cord is poor, often resulting in a permanent loss of motor and sensory function [1,2]. The inhibitory environment for axonal regrowth generated by the meningo-glial scar is the main obstacle to regeneration after lesion [3-5]. Current strategies to enhance functional regeneration after spinal cord injury (SCI) include gene therapy, biochemical and/or pharmacological treatment, and cell transplantation [6-8]. In this scenario, olfactory ensheathing cells (OECs) have attracted particular attention as a therapeutic cell transplantation strategy $[9,10]$. During mammalian lifespan, OECs are capable of ensheathing and guiding newly growing axons of olfactory sensory neurons from the olfactory mucosa to their targets in the CNS [11, 12]. Indeed, OECs have been successfully used in many transplantation experiments following SCI, with encouraging outcomes (e.g., [13-15]). The precise mechanisms

\section{J. Samitier}

Nanobioengineering Laboratory, . Institute for Bioengineering of Catalonia, 08028 Barcelona, Spain

\section{J. Samitier}

Department of Electronics, University of Barcelona, Centro de Investigaciòn Médica en Red, Biomecánica, Biomateriales y Nanotecnologìa (CIBERBBN), Barcelona, Spain

\section{Trepat}

University of Barcelona, 08028 Barcelona, Spain

\section{Trepat}

Institució Catalana de Recerca i Estudis Avançats (ICREA), 08010 Barcelona, Spain accounting for the observed recovery are not fully understood but may include promotion of axonal regeneration, remyelination, neuroprotection, and induction of neovascularization (see [9] for recent review). The migratory potential of OECs is crucial to their function [16]. However, studies of the migration capacity and behaviour of OECs after transplantation in SCI models have led to contradictory results [17-19]. Nevertheless, it has been demonstrated that in injured spinal cord, rat and human OECs migrate for shorter distances, in both rostral and caudal directions, compared to non-injured spinal cords [20]. At the molecular level, GDNF [21], Slit-2 [22, 23], NogoA [24, 25] and fibulin-3 [26] have been demonstrated to regulate OEC migration. In fact, we and others have demonstrated that the OEC migratory potential is largely impaired by myelin $[24,25,27,28]$ and that this inhibition may be partially overcome by treatment with NEP1-40 peptide [24] or antibodies against the myelin receptor Nogo receptor [25]. However, following SCI, myelin-associated inhibitors (MAIs) as well as chondroitin sulphate proteoglycans (CSPGs) and secreted semaphorins are overexpressed at the site of the lesion and they are exposed to lesioned axons for protracted times [29-31]. However, although OEC transplantation has been combined with enzymatic degradation of CSPGs [32-34], whether CSPG and secreted semaphorins can also inhibit both axon regrowth and OEC migration is unknown.

In a previous study, we determined the effects of myelin extracts and CSPG on OEC migration, using video timelapse, traction force microscopy and biochemical methods [24]. In the present study, we analysed the behaviour of OECs cultured on CSPGs- or Oligodendrocyte-Myelin Glycoprotein (OMgp)-coated substrates. CSPG-mediated inhibition of OEC migration can be abolished using ChABC. In addition, we genetically modified a stable cell line of OECs (TEG3 cell line [35]) to produce and secrete the extracellular domain of the Nogo receptor protein $[\mathrm{NgR}$ (Ecto) $]$ to enhance migration in myelin-derived inhibitors. In fact, $\mathrm{NgR}$ (Ecto) is a truncated form of the receptor that binds to MAIs, preventing their binding to the $\mathrm{NgR}$ complex by interacting with full-length $\mathrm{NgR} 1$ and blocking the intracellular signalling of MAIs [36, 37]. Moreover, following SCI, intrathecal and intraperitoneal injections of $\mathrm{NgR}$ (Ecto) improved axon regeneration of transected axonal tracts and functional recovery [38, 39]. Our results demonstrate that $\mathrm{NgR}$ (Ecto)-expressing OECs migrated longer distances in vitro in comparison to nonmodified OECs. In addition, we show that after implantation in a lesioned spinal cord of adult rats, $\mathrm{NgR}$ (Ecto)OECs also migrate longer distances than non-modified cells. Our results provide new insights toward improvement of the mechanisms of action and optimization of OEC-based cell therapy for SCI. 


\section{Methods}

Antibodies and biochemical reagents

The following antibodies were used at a dilution of 1:500 for immunohistochemistry and/or western blotting: $\mathrm{S} 100 \beta$ and $\beta 3$-Tubulin (TUJ-1, 1:4000) purchased from Abcam (Cambridge, MA, USA), glial fibrilary acidic protein (GFAP) and green fluorescence protein (GFP) antibodies from DAKO (Glostrup, Denmark), and p75 from Promega (Madison, WI, USA). NgR1 was a gift from B.L. Tang (Singapore). Alexa Fluor 488 goat anti-mouse and Alexa Fluor 568 goat anti-rabbit immunoglobulins were purchased from Molecular Probes (Leiden, Netherlands). The goat anti-mouse horseradish peroxidase (HRP) and rabbit anti-goat-HRP secondary antibodies used in Western blots were from DAKO. Tubulin (1:5,000), Phalloidin-Alexa 488, and DAPI were from Sigma (St. Louis, MO, USA). CSPG and OMgp proteins were purchased from R\&D Systems (Minneapolis, MN, USA). Myelin extract was obtained as [40] and NogoA-containing membranes as [41].

Cloning of the $\mathrm{NgR}$ ectodomain $[\mathrm{NgR}$ (Ecto)] and lentiviral production

The $\operatorname{NgR}$ (Ecto) construct (Supplementary Fig. S1) was prepared as follows: the cDNA of the region was cloned by PCR from adult mouse brain with the primers: $\mathrm{NgR}$ (Ecto) Forward 5' - AAA GGA TCC ATG AAG AGG GCC TCC TCC GGA-3', and NgR(Ecto) Reverse 5'-AAT GGA TCC TTA TCA AGC ACA ACC CTC TAA GTC ACT-3'. The $\mathrm{NgR}$ (Ecto) PCR fragment was extracted (QIAquick, QIAGEN, Hilden, Germany) and subcloned into the pLenti6/ V5-DEST vector (Invitrogen, Grand Island, NY, USA) into ApaI and BclI sites. This $\mathrm{NgR}$ (Ecto) vector was then sequenced to ensure correct nucleotide sequence. Subsequently, lentiviral particles were produced by transient transfection of 293FT cells with Lipofectamine 2000 (Invitrogen), using the $\mathrm{NgR}$ (Ecto) vector, the second generation packaging construct psPAX (Tronolab, Lausanne, Switzerland) and the envelope plasmid pMD2G (Tronolab). 293FT cells (Invitrogen) were cultured in DMEM supplemented with $10 \%$ foetaB calf serum and without antibiotics before transfection. Medium was changed and supplemented with antibiotics after $6 \mathrm{~h}$. Medium supernatants containing viral particles were harvested 24 and $48 \mathrm{~h}$ later and concentrated by ultracentrifugation $(2 \mathrm{~h}$ at $26,000 \times g$ at $4^{\circ} \mathrm{C}$ ).

TEG3 cultures and infection strategy

The immortalized clonal cell line TEG3, which contains the SV40 large $\mathrm{T}$ antigen stable transfectant of OEG primary cultures, was used [35]. Cells were maintained in ME10: DMEM-F12 (Invitrogen) supplemented with $10 \%$ bovine calf serum (SAFC Biosciences, Lanexa, VA, USA), $20 \mu \mathrm{g} / \mathrm{ml}$ pituitary extract (Invitrogen), $2 \mu \mathrm{M}$ forskolin (Sigma), $1 \%$ penicillin-streptomycin, and $1 \%$ fungizone (Invitrogen). TEG3 cells were transfected using a lentivirus carrying the $\mathrm{NgR}$ (Ecto) construct and/or one lentivirus carrying the eGFP construct (Supplementary Fig. S1). Cells in passage 2 were plated at 2,000 cells $/ \mathrm{cm}^{2}$ and incubated with one of the lentiviruses for $48 \mathrm{~h}$. Then, the medium was changed and the cells cultured as described above with the addition of Blasticidin ( $3 \mu \mathrm{g} / \mathrm{ml}$, Sigma) to the medium in the case of the $\mathrm{NgR}$ (Ecto). For double transfection, cells were first incubated with the $\mathrm{NgR}$ (Ecto) lentivirus, and afterwards with the eGFP. Single clones were selected with cloning disks (Sigma) and expression of $\mathrm{NgR}$ (Ecto) was tested in these clones by western blot. Selected clones were grown in ME10 media.

Immunocytochemical methods on TEG3 cells

Glass coverslips (12 mm diameter) were coated with proteins essentially as described [36]. Briefly, coverslips were pre-coated with Poly-L-Lysine $10 \mu \mathrm{g} / \mathrm{ml}$ dissolved in $0.1 \mathrm{M}$ PBS ( $\mathrm{pH} 7.3$ ) and then washed. They were coated with laminin $(2 \mu \mathrm{g} / \mathrm{ml}$, dissolved in $0.1 \mathrm{M}$ PBS $)$ and washed again with $0.1 \mathrm{M}$ PBS. $\mathrm{NgR}$ (Ecto)-TEG3 cells were seeded onto substrate-coated coverslips in ME10 medium. Cells were cultured for $20 \mathrm{~h}$ and then the coverslips were fixed in $4 \%$ buffered paraformaldehyde for $30 \mathrm{~min}$, permeabilized with $0.1 \%$ Triton X-100, and blocked with $10 \%$ normal serum in both diluted in 0.1 M PBS. Cells were sequentially incubated overnight with primary antibodies at $4{ }^{\circ} \mathrm{C}$ and with Alexa Fluor-tagged secondary antibodies for $1 \mathrm{~h}$. After rinsing in $0.1 \mathrm{M}$ PBS, cells were stained with $0.1 \mathrm{M}$ DAPI diluted in $0.1 \mathrm{M}$ PBS for $10 \mathrm{~min}$, rinsed in $0.1 \mathrm{M}$ PBS, and mounted on Fluoromount ${ }^{\mathrm{TM}}$ (Vector Labs, Burlingame, CA, USA); they were then analysed using a fluorescence microscope equipped with a cooled camera (Olympus BX61 + DP12L camera).

Nogo66-AP binding assays

Binding experiments were developed essentially as described [42]. TEG3 cells (75\% confluence) were fixed in methanol at $-80{ }^{\circ} \mathrm{C}$ for $5 \mathrm{~min}$. After rehydrating in $0.1 \mathrm{M}$ PBS, they were overlaid with different concentrations of Nogo66-AP (kindly provided by Zhigang He) diluted in Hanks Balanced Salt Solution (HBSS, Invitrogen) and $20 \%$ FCS for $90 \mathrm{~min}$, washed, and fixed in $3.7 \%$ paraformaldehyde. Endogenous phosphatase was heat inactivated at $65^{\circ} \mathrm{C}$. The AP-fusion protein was viewed through an enzymatic reaction with a solution containing 
$34 \mathrm{M}$ of Nitroblue tetrazolium and $18 \mathrm{M}$ of 5-bromo4chloro-3-indolylphosphate (Invitrogen). For competition experiments, $\mathrm{NgR}$ (Ecto) was added at different concentrations during Nogo66-AP incubation. AP levels (blue reaction) were measured using a spectrophotometer (Dynex Technologies, VA, USA).

In vitro experiments with cerebellar granule neurons (CGNs)

CGNs from P5-P7 mouse (CD1 strain, Charles River, Lyon, France) pups were dissociated by combined trypsinization as described previously [43]. Cells were placed in 24-well tissue culture dishes (Nunc, Roskilde, Denmark) on coated coverslips (see below) and grown for 24-48 h in DMEM medium supplemented with N2 and B27 (Invitrogen). The procedures were used to treat cells with MAIs or myelin; the cell surface was coated with purified myelin essentially as described [40]. After treatments with the TEG3-produced $\mathrm{NgR}$ ectodomain, cells were fixed in $4 \%$ buffered paraformaldehyde and stained with TUJ-1 antibody and Alexa Fluor 568-tagged secondary antibody. After rinsing, coverslips were mounted in Fluoromount $^{\mathrm{TM}}$ and photodocumented. Neurite length in cultured CGNs was assessed following image acquisition using Image ${ }^{\mathrm{TM}}$ software. A total of 50-57 neurons were measured in each condition.

Time-lapse analysis of cell migration

Fluorodish cell culture dishes (World Precision Instruments, Sarasota, FL, USA) were coated with laminin or myelin as above. $5 \times 10^{4}$ cells were seeded in the coated dishes and 20-24 h later the time-lapse analysis was performed. Culture dishes were transferred to an LCI system (Live Cell Instruments, Seoul, Korea) for $20 \mathrm{~h}$. Tracking was performed with an inverted Olympus microscope IX71 (20X Objective) and images (5 megapixels each) were captured with an Olympus XC50 camera (150 frames, one frame every $8 \mathrm{~min} .20 \mathrm{~h}$ in total). Cell tracking allows analysis of the scrolling speed and frame position (Xt, Yt). The multi-tracking analysis was performed with Image ${ }^{\mathrm{TM}}$ software using the plugin mTrackJ (Biomedical Imaging Group Rotterdam of the Erasmus MC-University Medical Center Rotterdam, Netherlands).

In vitro experiment on microfluidic devices

Embryonic cortical neurons were cultured in compartmented microchips (Cat. SND900, Xona ${ }^{\mathrm{TM}}$ microfluidics, Temecula, CA, USA) (see [44] for details). Both reservoirs (axonal and soma) were coated overnight with Poly-DLysine to ensure that the protein also coated the surface of the $900 \mu \mathrm{m}$ long bridge channels. The following day the axonal compartment was also coated with OMgp as above. To avoid diffusion of the OMgp from the axonal to the soma compartment, a larger amount $(>15 \%)$ of medium was added to the soma compartment during the experiment. Cortical neurons were seeded and after an additional 2 days in vitro, eGFP-TEG3 or eGFP-NgR(Ecto)-TEG3 cells $\left(2 \times 10^{5}\right)$ were seeded in the axonal compartment. After an additional 10 days in vitro, microchips were fixed in $4 \%$ buffered paraformaldehyde and rinsed in 0.1 M PBS. After rinsing in $0.1 \mathrm{M}$ PBS, chips were incubated with TUJ-1 and eGFP antibodies for two days at $4{ }^{\circ} \mathrm{C}$ and $6 \mathrm{~h}$ with the appropriate Alexa-tagged secondary antibodies. After rinsing, both soma and axonal compartments were filled with Fluoromount ${ }^{\mathrm{TM}}$ in $0.1 \mathrm{M}$ PBS (2:1 diluted) and photodocumented. The length of the cortical neurons in the axonal compartment was measured using Image ${ }^{\mathrm{TM}}$ software. A total of 20 chips were analysed in each condition.

\section{Traction force microscopy measurements}

Cell tractions were evaluated using constrained Fourier transform traction microscopy (FTTM) [45]. PAA gels were coated with laminin, CSPG, or OMgp as described [24], and cells were cultured over the PAA-coated gels. Briefly, to obtain a stiff gel of $12 \mathrm{kPa}$ Young Modulus (PAA), $265 \mu \mathrm{l}$ of an Acrylamide/Bis-acrylamide mixture (15\% Acrylamide and $6.5 \%$ Bis-acrylamide, Bio-Rad) were dissolved in ultrapure water containing $0.4 \%$ of $0.2 \mathrm{~m}$ diameter red fluorescent beads (Invitrogen), $0.5 \%$ ammonia persulfate, and $0.05 \%$ TEMED (Bio-Rad). For multi-tracking, the mixture was added to the centre of the dish, which was then coated and stored overnight at $4{ }^{\circ} \mathrm{C}$. The displacement field was calculated by comparing fluorescent microbead images obtained during the experiment with a reference image taken at the end of the experiment after the trypsinization and the consequent detachment of OECs from the underlying substrate. The projected cell area was calculated with Matlab ${ }^{\mathrm{TM}}$, based on the manual tracing of the OEC contours determined by a phase contrast image obtained at the start of the experiment. A particle imaging velocimetry algorithm [46] was used to determine the deformation of the substrate caused by the traction forces. The number of analysed cells in each condition is indicated in the Results section.

Surgical procedures and cell transplantation

Adult female Sprague-Dawley rats (9 weeks old; 250-300 g weight) were used in the spinal cord experiments. The animals were housed with free access to food and water at room temperature of $22 \pm 2{ }^{\circ} \mathrm{C}$ under a 12:12 h light-dark cycle. The experimental procedures 
were approved by the ethical committee of the Universitat Autonoma de Barcelona and the IBEC in accordance with European Directive 86/609/EEC. Under anaesthesia with ketamine $(90 \mathrm{mg} / \mathrm{kg})$ and xylacine $(10 \mathrm{mg} / \mathrm{kg})$ and aseptic conditions, laminectomy was performed in T8-T9 vertebra and a cord contusion of 200 Kdyns was induced using an Infinite Horizon Impactor (Precision System and Instrumentation, Kentucky, USA). The cells for transplantation (eGFP-TEG3 or eGFP-NgR(Ecto)-TEG3) were suspended in L15 medium (Invitrogen) at 50,000 cells/ $\mu$ l and maintained in ice during the time of surgery. 30 min after the lesion, using a glass needle $(100 \mu \mathrm{m}$ internal diameter, Eppendorf, Hamburg, Germany) coupled to a $10 \mu \mathrm{l}$ Hamilton syringe (Hamilton \#701, Hamilton Co, NV, USA), $6 \mu$ of the corresponding cell suspension was intraspinally injected ( $1 \mathrm{~mm}$ deep into the spinal cord, 2 injections of $3 \mu \mathrm{l}$ each, one at each side $1 \mathrm{~mm}$ lateral to the lesion point), with a total of 150,000 cells per injection (300,000 cells/rat). A perfusion speed of $2 \mu \mathrm{l} / \mathrm{min}$ was controlled by an automatic injector (KDS 310 Plus, Kd Scientific, Holliston, MA, USA), and the needle tip was maintained inside the tissue $3 \mathrm{~min}$ after injection to avoid liquid reflux. A total of six rats were used (3 rats received eGFP-TEG3 cells, and the other 3 eGFP-NgR(Ecto)-TEG3 cells). The wound was sutured by planes and the animals allowed to recover in a warm environment. Bladders were expressed twice a day. To prevent infection, amoxicillin $(500 \mathrm{mg} / \mathrm{l})$ was given in the drinking water for one week.

Tissue processing

Seven days post-implantation, rats were deeply anaesthetized (pentobarbital $60 \mathrm{mg} / \mathrm{kg} \quad$ b.w. i.p.) and intracardially perfused with $4 \%$ paraformaldehyde in $0.1 \mathrm{M}$ PBS. The spinal cord segment from $1.5 \mathrm{~cm}$ rostral to $1.5 \mathrm{~cm}$ caudal to the injection $( \pm 3 \mathrm{~cm}$ total length) was harvested and post-fixed in the same fixative solution for $24 \mathrm{~h}$ and cryopreserved in $30 \%$ sucrose. For GFP-positive cell localization, $30 \mu \mathrm{m}$ thick longitudinal cryostat sections of the spinal cord segment were obtained. Spinal cord sections of cell-transplanted rats were processed for immunohistochemistry against GFP and GFAP. Tissue sections were incubated with 0.1 M PBS Triton X-100, $5 \%$ foetal bovine serum during $4 \mathrm{~h}$ and $24 \mathrm{~h}$ at room temperature with with primary antibodies at $4{ }^{\circ} \mathrm{C}$. After washing, sections were incubated for $2 \mathrm{~h}$ at room temperature with the secondary antibody. Slides were dehydrated and mounted with Citoseal 60 (Thermo Fisher Scientific, Madrid, Spain). For analysis, images (10 megapixels) were obtained with a digital camera (Leica DFC 550) attached to the microscope (Leica AF700). Starting from the injection points, 11 consecutive sections of the length of approximately $200 \mu \mathrm{m}$ were captured. GFP-positive cells in each section were counted.

Statistical analysis

Summary data are expressed as mean \pm S.E.M (standard error of the mean) of at least three independent experiments (unless indicated). Data were analysed using Bonferroni post hoc test (Multiple comparison test) using Prism 5 (Mac OsX, Grahpad). A value of $* * P<0.05$ was considered statistically significant.

\section{Results}

Reduced migration and traction forces in cultured TEG cells mediated by CSPGs and OMgp

TEG3 is a clone OEC line that shows similar growth promoting potential to non-modified OECs (e.g., [35]. In addition, previously published data reported that TEG3 cell migration is inhibited by myelin [24] as happens with nonmodified OECs [25]. Because of the lamellipodial activity of the OECs that seems to play a crucial role in OEC migration [47] and regeneration properties [48], we analysed the membrane dynamics in OECs over different substrates (Fig. 1). TEG3 cells growing on laminin-coated substrates showed a bipolar morphology with numerous dynamic filopodia and lamellipodia (Supplementary Movie 1). The migration of these cells is similar to those observed in cultured fibroblasts (e.g., NIH/3T3 fibroblasts; ATCC CRL-1568) with random trajectories (see below). LifeActeGFP transfected TEG3 cells showed an intense remodelling of the Actin cytoskeleton during migration (Supplementary Movie 2 and Fig. 1a). Thus, video timelapse experiments used to analyse the dynamics of the cell membrane showed increased dynamics of TEG3 growing over laminin (Fig. 1a, d) compared with TEG3 cells growing on CSPG (Fig. 1b, e) or OMgp-coated (Fig. 1c, f) substrates. This also correlates with decreased cell protrusions observed in GFP immunoreacted cells (Fig. 1a-c) and in scanning electron microscopy (SEM) observations (Fig. 1g-i).

Next, TEG3 migration over laminin, CSPG-, and OMgp-coated substrates was monitored for $20 \mathrm{~h}$ in video time-lapse experiments (20X objective; one frame every $8 \mathrm{~min}$ )(Fig. 2 and Supplementary Movies 3-5). A threeaxis plot ( $x / y$ position vs time (hours)) revealed higher motile persistence on laminin coated (Fig. 2d) than on CSPG- (Fig. 2e) or OMgp-coated (Fig. 2f) substrates. Quantitatively, the migration speed of TEG3 s cells over laminin was $0.81 \pm 0.03 \mu \mathrm{m} / \mathrm{min}$. In contrast, TEG3 cells 

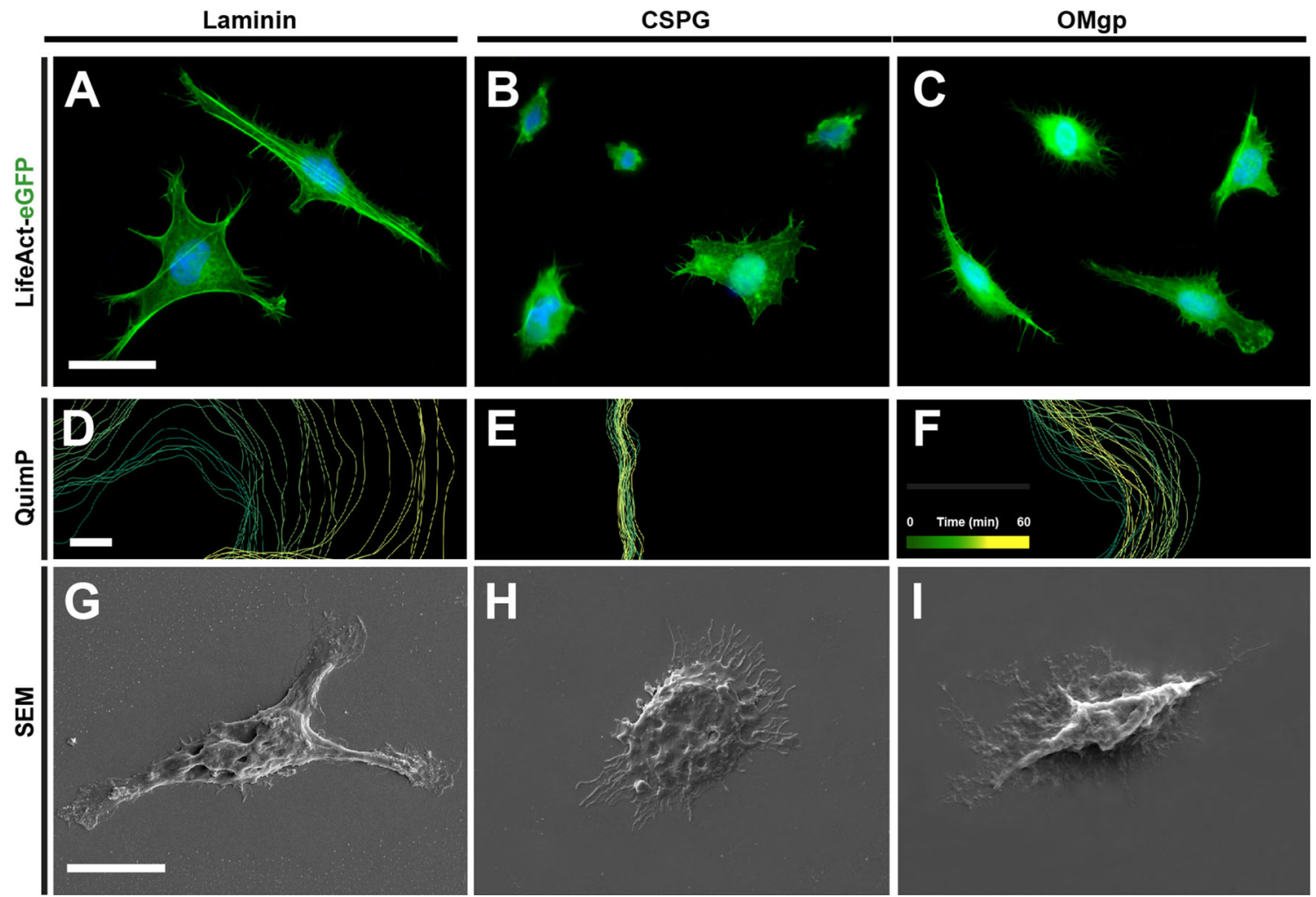

Fig. 1 Morphological changes triggered by CSPG and OMgp in cultured TEG3 cells. a-i LifeAct-eGFP (a-c), QuimP analysis $(\mathbf{d}-\mathbf{f})$, and SEM ( $\mathbf{g}-\mathbf{i})$ microscopy photographs of TEG3 cells growing on laminin- (a, d, g), CSPG- (b-h), and OMgp- $(\mathbf{c}, \mathbf{f}, \mathbf{i})$ coated substrates. Note the large decrease in F-Actin containing lamellipodia and membrane dynamics in the presence of CSPG and OMgp. In the
QuimP analysis (d-f), the limit of the plasma membrane is delineated by different colour lines [by time $=0$ (green) to $60 \mathrm{~min}$ (yellow)]. Note that yellow lines are in between green lines, in CSPG (h) and OMgp (i), in contrast to laminin (b), which suggests that cells are unable to generate protrusive forces. Scale bars $a$ and $g=20 \mu \mathrm{m}$; pertain to $\mathbf{b}, \mathbf{c}$ and $\mathbf{h}-\mathbf{i}$, respectively. $d=5 \mu \mathrm{m}$ pertains to $\mathbf{e}-\mathbf{f}$ growing over CSPG- or OMgp-coated substrates showed a dramatic decrease in the migrated speed ranging from 63 to $76 \% \quad(0.27 \pm 0.05 \mu \mathrm{m} / \mathrm{min} \quad(\mathrm{OMgp}, \quad 10 \mu \mathrm{g} / \mathrm{ml}) \quad$ to $0.19 \pm 0.02 \mu \mathrm{m} / \mathrm{min}(\mathrm{CSPG} ; 25 \mu \mathrm{g} / \mathrm{ml}$ ).

Mounting evidence demonstrates that cells generate traction forces against their substrate during adhesion and migration, and traction forces are used by cells to sense the extracellular matrix in healthy and unhealthy conditions (e.g., [49, 50]). Thus, using traction force microscopy (TFM), we aimed to determine the distribution of traction forces in TEG cells cultured on a well-characterized polyacrylamide (PAA) gel, which is linearly elastic, optically clear, and suitable for protein conjugation ([51] see for details). Using TFM, we observed that cells seeded on laminincoated substrates transferred higher strain energy $(0.01389 \pm 0.004, \mathrm{PJ} ; n=16)$ (Fig. $2 \mathrm{~h})$ to their underlying substrate than those seeded on CSPG- $(0.00018 \pm 0.0001$, PJ; $n=35$ ) (Fig. 2i) or OMgp-coated substrate $(0.00032 \pm 0.0001, \mathrm{PJ} ; n=29)$ (Fig. 2j) (laminin vs CSPG $t=6.362$ and laminin vs OMgp $t=6.086 ; P<0.05)$.
Fig. 2 Migratory behaviour and traction force strain of TEG3 cells in laminin-, CSPG- and OMgp-coated glass substrates. Examples of TEG3 cell migration on laminin- (a), CSPG- (b), and OMgp(c) coated glass substrates. Each cell trajectory is labelled with a different colour line after the software analysis (Image $\left.{ }^{\mathrm{TM}}\right)$. (df) Examples of three-axis representation of the trajectories of identified TEG3 cells in the focal plane $(x, y)$ along time $(z$ axis, $\mathrm{h})$ on laminin (d), CSPG (e) and OMgp (f). Note that identified TEG3 cells do not modify their $(x, y)$ position over time (e and $\mathbf{f})$ with few of them showing small displacements (arrowhead) compared to laminin (d). $\mathbf{g}$ Histograms showing the speed ( $Y$ axis) of cultured TEG3 cells on laminin (black bars), and two concentrations of CSPG (grey bars) and OMgp (open bars). $\mathbf{h}-\mathbf{j}$ Quantitation of cellular traction forces of cultured TEG3 cells in PAA-laminin (h), PAA-CSPG (i) and PAAOMgp (j). A phase contrast image of examples of cultured cells is shown on the left side. The scale in $\mu \mathrm{m}$ is also displayed on the lower left side of each image. In addition, the force map of cultured cells is shown in the right column. Arrows indicate the direction of the bead displacement. The colour scale indicates the magnitude of the cellular traction force measured in $\mathrm{Pa}$. Data in (g) are represented as mean \pm S.E.M. Asterisks in (g) indicate statistical differences $(* * P<0.05$, one-way ANOVA Bonferroni post hoc test: laminin vs CSPG $(12 \mu \mathrm{g} / \mathrm{ml}) t=15.03$; laminin vs CSPG $(25 \mu \mathrm{g} / \mathrm{ml})$ $t=17.01 ;$ laminin vs OmGP $(5 \mu \mathrm{g} / \mathrm{ml}) t=14.90 ;$ and laminin vs OmGP $(10 \mu \mathrm{g} / \mathrm{ml}) t=15.10)$ 

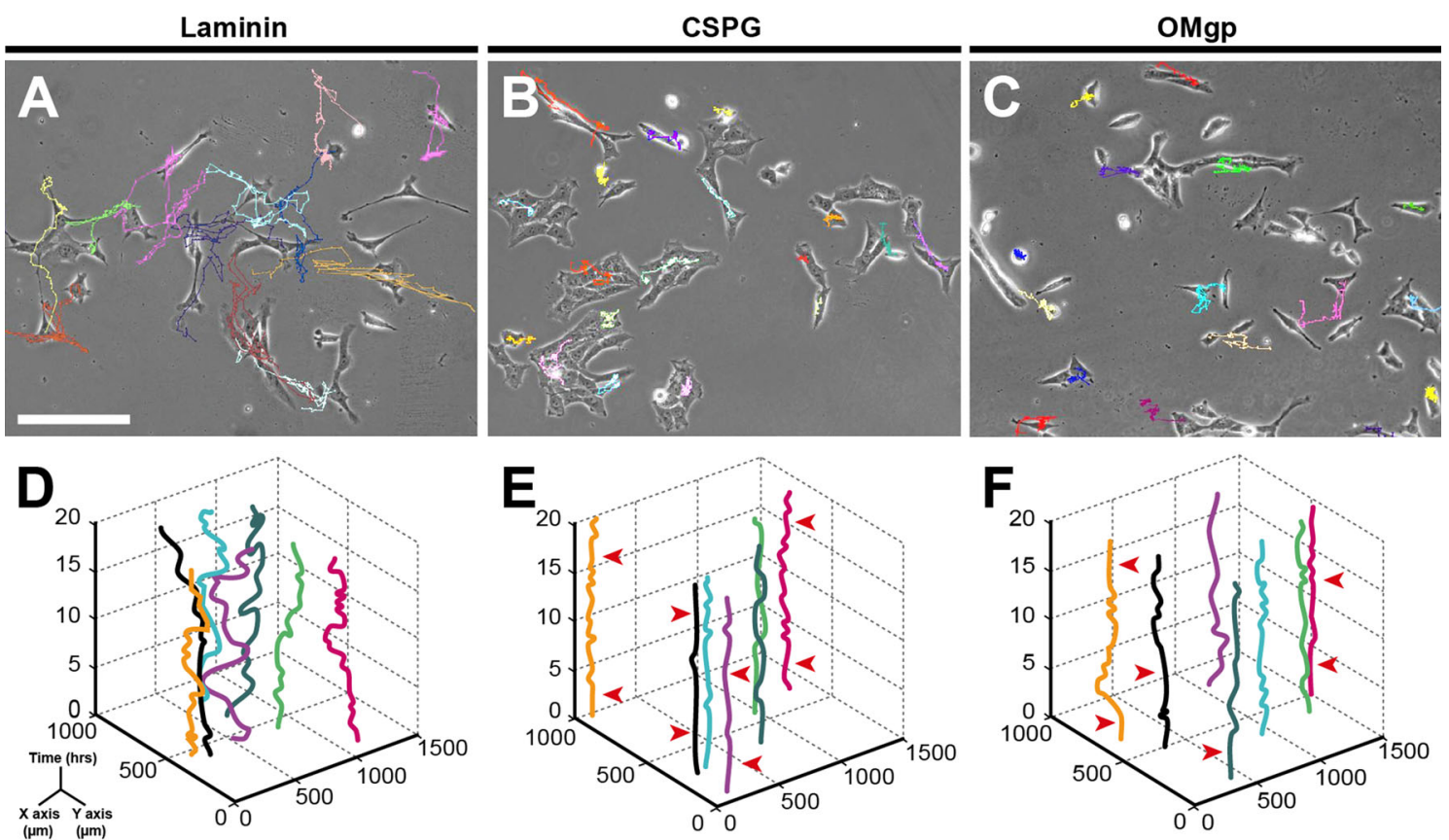

G
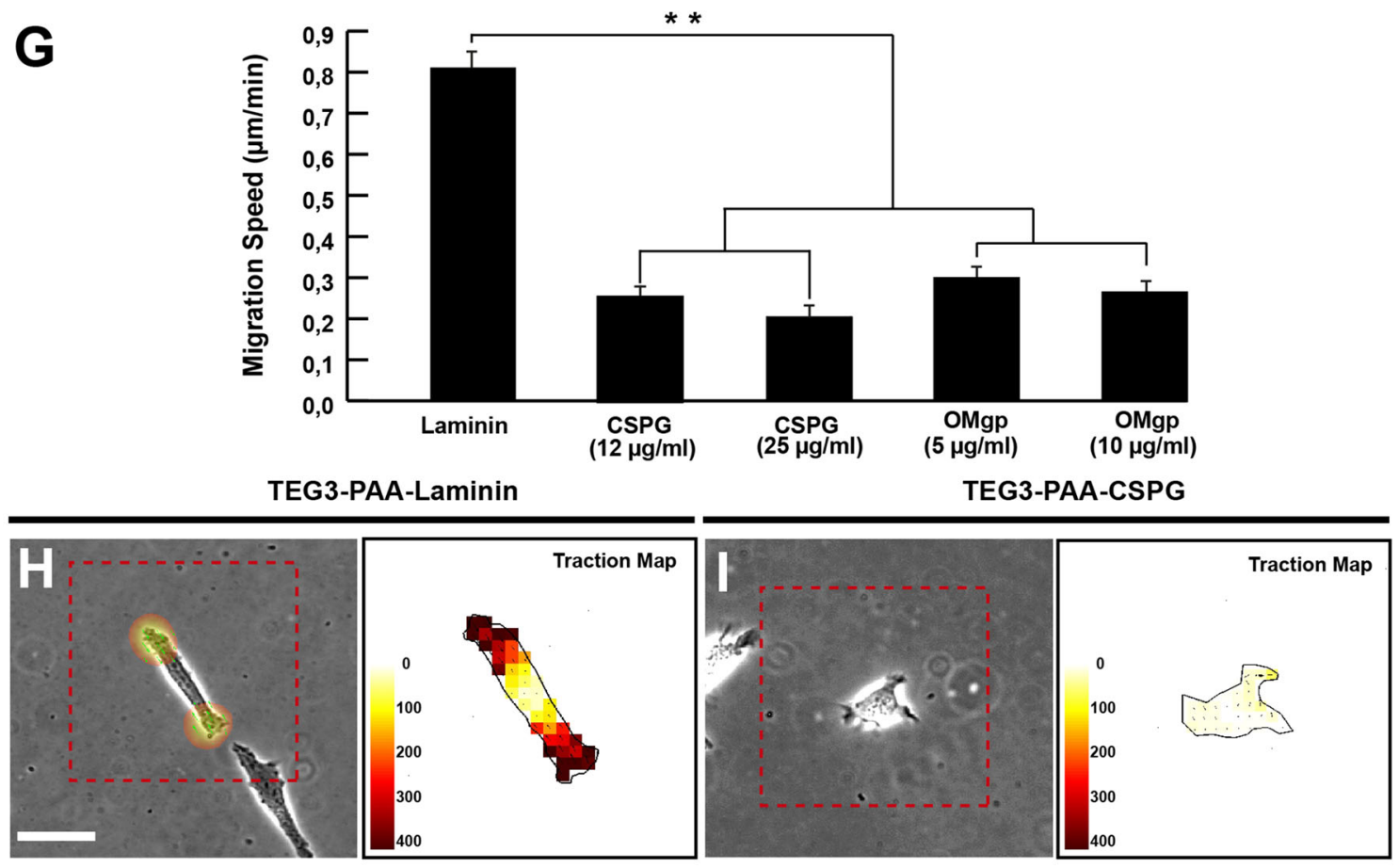

TEG3-PAA-OMgp

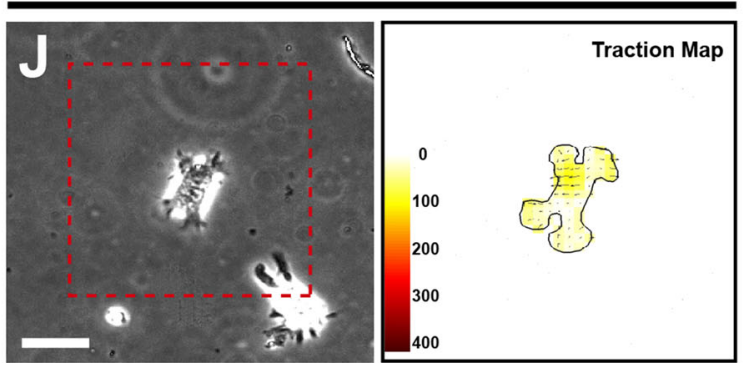



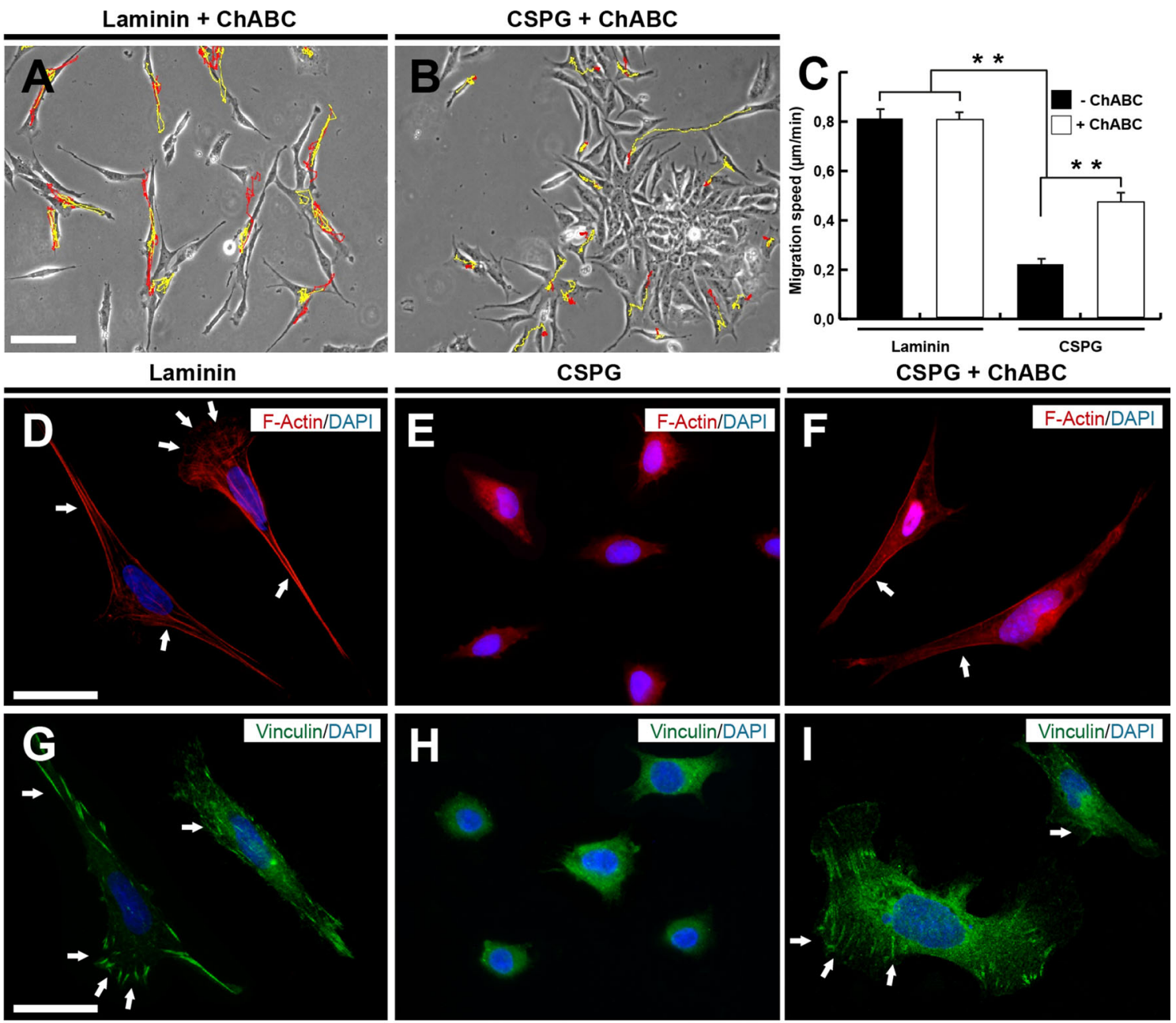

CSPG + ChABC
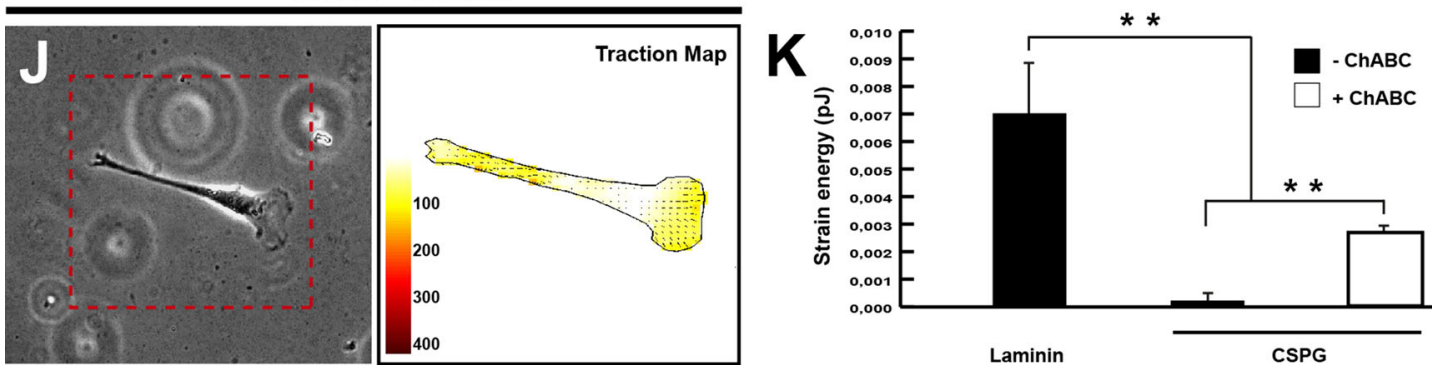

Fig. 3 Overcoming CSPG inhibition of TEG3 migration by ChABC. (a-b) Examples of the ChABC effects of individual TEG3 migration on laminin- (a) and CSPG- (b) coated glass substrates. The trajectory of selected TEG3 cells without ChABC treatment is labelled in red in (a) and (b). Yellow lines show the changes observed after incubation with $\mathrm{ChABC}$ in the selected cells. c Histogram showing the results of the time-lapse analysis and the effect of the ChABC incubation. di Fluorescein photomicrographs illustrating examples of TGE cells growing on laminin $(\mathbf{d}, \mathbf{g}), \mathrm{CSPG}(\mathbf{e}, \mathbf{h})$ and $\mathrm{CSPG}+\mathrm{ChABC}(\mathbf{f}, \mathbf{i})$. Cells were immunoreacted to F-Actin (d-f) and vinculin (gi) antibodies and counterstained with DAPI. Arrows in (d) and (f) point to stress fibres and in (g) and (i) to vinculin-positive focal contacts. j Quantitation of cellular traction force of cultured TEG3

cells in PAA-CSPG + ChABC. A phase contrast image of TEG3 cultured cells is shown. The scale and the force map are also shown. Arrows indicate the direction of the bead displacement and the colour scale indicates the magnitude of the cellular traction force measured in $\mathrm{Pa}$ as in Fig. 2. k Histogram illustrating the quantitative results of the TFM analysis. Data in (c) are represented by mean \pm S.E.M. Scale bars $a=200 \mu \mathrm{m}$ pertains to b. $c$ and $g=200 \mu \mathrm{m}$ pertains to $\mathbf{e}$, $\mathbf{f}$ and $\mathbf{g}, \mathbf{i}$ respectively. Asterisks in (c) (laminin vs CSPG ( - ChABC) $t=17.53$; laminin vs CSPG ( + ChABC) $t=10.03$; CSPG vs CSPG $(+\mathrm{ChABC}) t=7.759)$ and (k) (laminin vs CSPG (-ChABC) $t=6.374$; laminin vs CSPG $(+\mathrm{ChABC}) t=5.590 ; \mathrm{CSPG}$ vs CSPG $(+$ ChABC) $t=5.03)$ indicate statistical differences $(* * P<0.05$ one-way ANOVA Bonferroni post hoc test) 
Effects of ChABC treatment on TEG3 cell migration and traction forces over CSPG-containing substrates

The bacterial enzyme ChABC liberates chondroitin suphate GAGs from CSPG core proteins to render a more permissive substrate for axonal outgrowth [34, 52]. ChABC acts on chondroitin 4-suphate, chondroitin 6-sulphate, and dermatan sulfated proteogycans, and acts very slowly on hyaluronate. This enzyme has been used to promote axon regeneration in lesioned spinal cord in single and combined treatments (e.g., [34, 53-55]). In fact, ChABC has been used in combination with OECs $[32,56]$, and the expression of $C h A B C$ has also been directed to Schwann cells [57] and astrocytes [58] with relevant results. In our study, TEG migration and traction forces were decreased by CSPGs (see above). Thus, we aimed to determine whether $\mathrm{ChABC}$ treatment affected intrinsic OEC migratory properties and whether it was able to rescue their migration when cultured over CSPGs (Fig. 3). Control experiments demonstrated that $\mathrm{ChABC}$ treatment did not modify the migration or the traction forces of cultured TEGs over laminin (Fig. 3a, c and Supplementary Movie 6), myelin, or OMgp (not shown). TEG3 migration over CSPG-coated substrates was $0.19 \pm 0.05 \mu \mathrm{m} / \mathrm{min}$ (CSPG; $25 \mu \mathrm{g} / \mathrm{ml}) . A=60 \%$ increase in the migratory speed was observed after treatment with $\operatorname{ChABC}(0.48 \pm 0.07 \mu \mathrm{m} /$ min) (Fig. 3b, c and Supplementary Movie 7). F-actin and Vinculin staining on TEG3 cells growing on CSPG-coated substrates demonstrated increased lamellipodia and the presence of Vinculin-positive aggregates after ChABC treatment (Fig. 3d-i). In parallel, these increased Vinculin aggregates correlated with increased traction force as determined with TFM $(0.00179 \pm 0.0004, \quad \mathrm{PJ} ; n=35)$ (Fig. 3j-k).
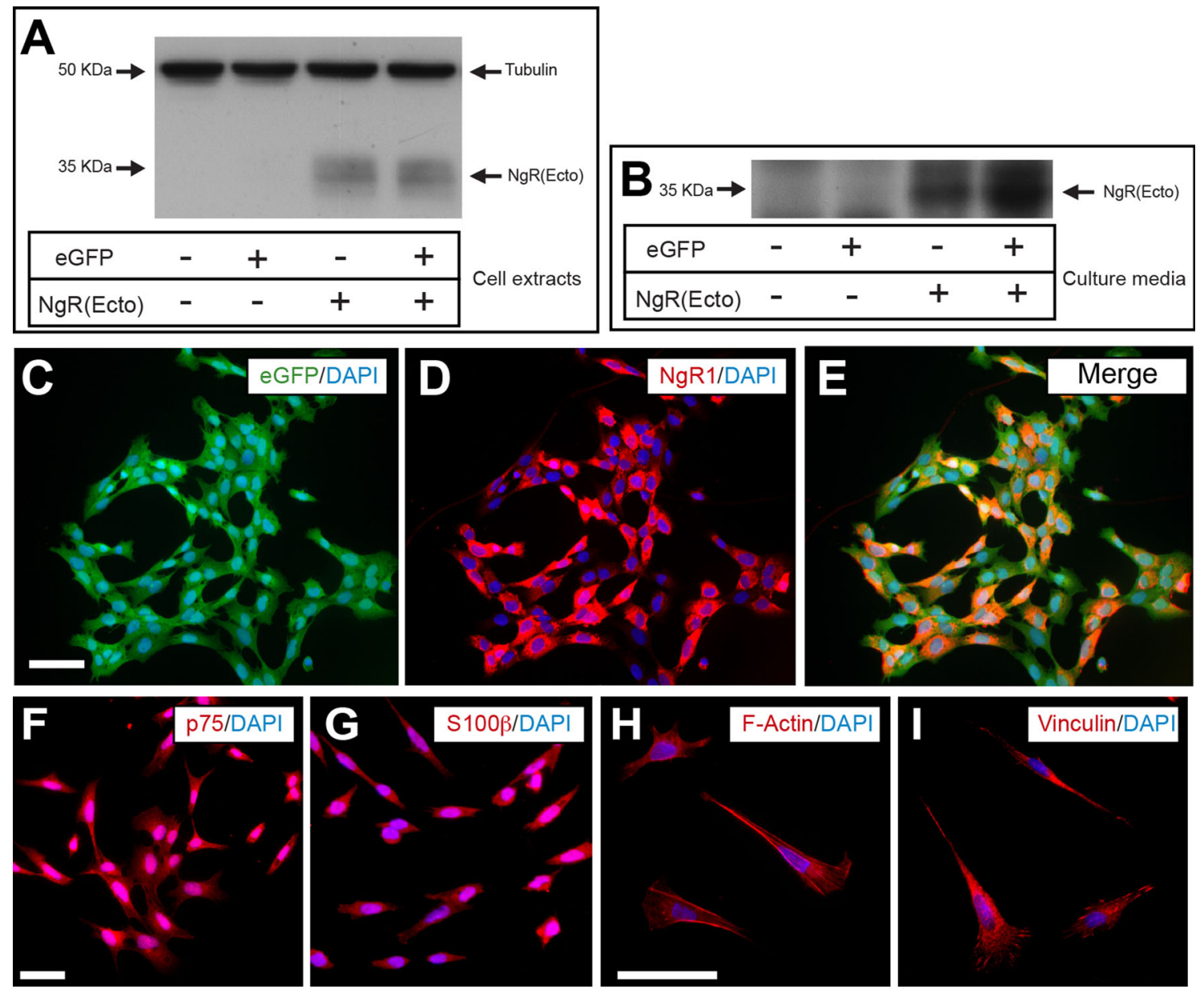

Fig. 4 Generation of the TEG3 cell lines overexpressing NgR(Ecto). a Western blot illustrating the expression of the NgR(Ecto) in TEG3 cells after lentiviral delivery of eGFP $(+$ or -$)$ and $\mathrm{NgR}($ Ecto) $(+$ or -$)$. Arrows point to the proteins of interest. Tubulin was immunoblotted as control protein. b Western blotting illustrating the presence of $\mathrm{NgR}$ (Ecto) in the culture media of TEG3 cells after the

lentiviral delivery of eGFP and $\mathrm{NgR}$ (Ecto) as above. c-e Example of the expression of eGFP (e) and NgR1 (i) in double-infected cells. $\mathbf{f}-$ i Fluorescence photomicrographs of eGFP-NgR(Ecto)-TEG3 cells immunoreacted to p75 (f), S100 $\beta$ (g), F-Actin (h), and vinculin (i) detection. Scale bars $c$ and $f=200 \mu \mathrm{m}$ pertains to d, e and g respectively. $h=50 \mu \mathrm{m}$ pertains to I 
Generation and characterization of $\mathrm{NgR}$ (Ecto)-TEG3 cells

TEG3 cell lines producing and secreting the extracellular domain (1-310 aa) of the $\mathrm{NgR} 1$ receptor were generated by lentiviral infection and selected with Blasticidin (see Methods for details). In addition, selected clones were infected with eGFP-expressing lentivirus (Fig. 4). Clones
(>95\% eGFP-NgR(Ecto)-TEG3) were selected by the expression levels of the ectodomain. With western blotting, we detected the ectodomain in both cell extracts and in cultures (Fig. 4a and Supplementary Fig. S2). eGFP coexpression in $\mathrm{NgR}$ (Ecto) producing cells did not modify the expression of ectodomain (Fig. 4a-c). In addition, eGFP-positive NgR(Ecto)-TEG3 cells maintained p75 or S100 $\beta$ expression (Fig. 4d, e) and displayed the range of
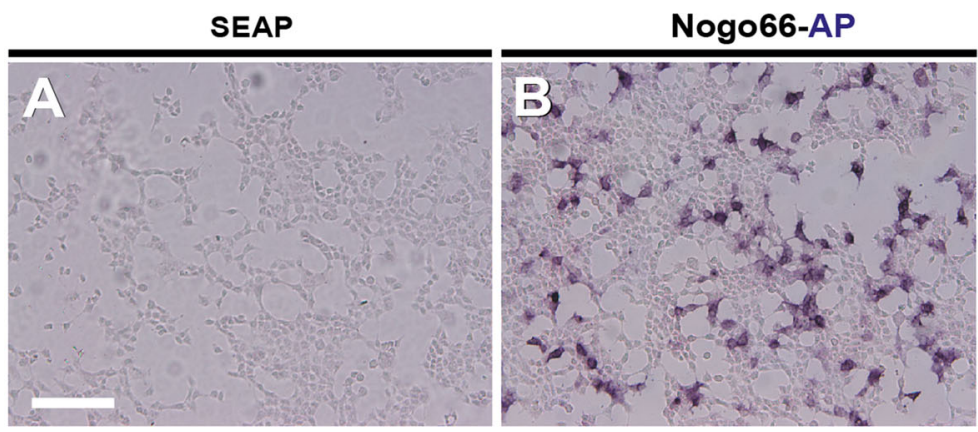

\section{Nogo66-AP + NgR(Ecto)}
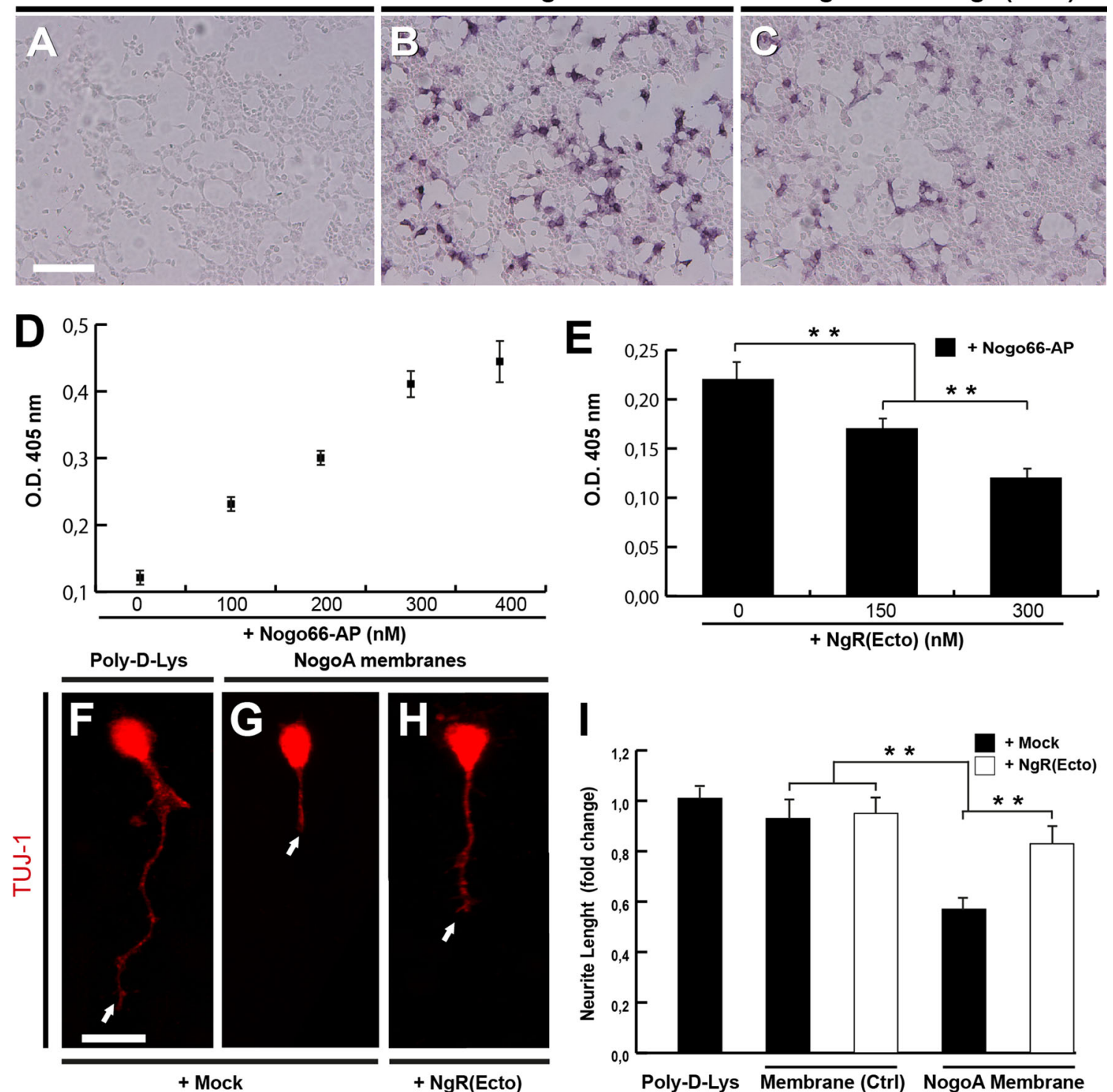

Fig. 5 The $\mathrm{NgR}$ (Ecto) generated by engineered TEG3 cells is functional. a-e Binding experiments of $\mathrm{NgR}$ (Ecto) in TEG3 cells. TEG3 cells were incubated with mock media (obtained from cells transfected with empty vector; SEAP) (a), $300 \mathrm{nM}$ Nogo66-AP (b) and $300 \mathrm{nM}$ Nogo66AP $+300 \mathrm{nM} \mathrm{NgR(Ecto)} \mathrm{(c).} \mathrm{Note} \mathrm{the}$ decrease in the AP labelling in (c) compared to (b). Increasing levels of O.D. at different Nogo66-AP can be seen in (d). Histogram illustrating the quantitative results of the experiment is presented in (c). $\mathbf{f}-\mathbf{i} \operatorname{NgR}$ (Ecto) induce large neurite extension of cultured CGN

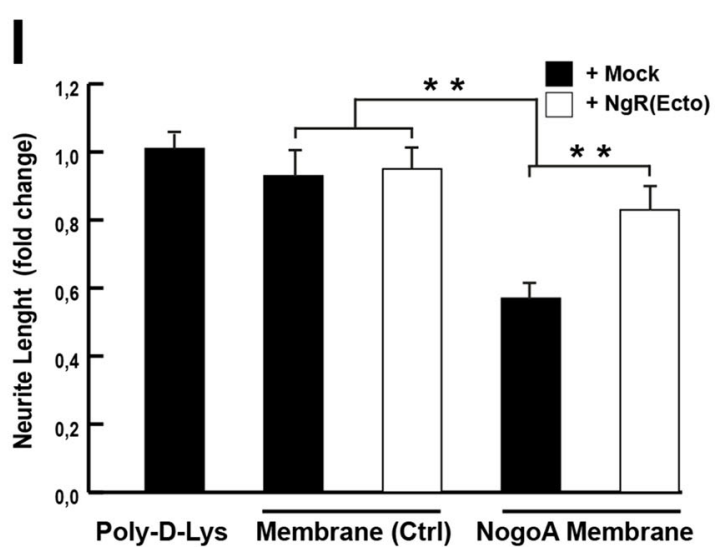

over Poly-L-Lys (f) or NogoA (g-h) containing membranes, in the presence (i) or absence (h) of $150 \mathrm{nM} \mathrm{NgR(Ecto).} \mathrm{Arrows} \mathrm{in} \mathrm{(f-h)}$ point to the end of the measured CGNs neurites. Data in (e) and (i) are represented by mean \pm S.E.M. Scale bars $a=1000 \mu \mathrm{m}$ pertain to $\mathrm{b}$ and c. $f=30 \mu \mathrm{m}$ pertains to $\mathrm{g}$ and h. Asterisks in (e) and (i) indicate statistical differences (e.g., Membrane + mock vs NogoA membrane + mock $t=18.99$; NogoA membrane + mock vs NogoA membrane $+\operatorname{NgR}$ (Ecto) $t=17.08 ; * * * P<0.05$, one-way ANOVA Bonferroni post hoc test) 
morphologies (astrocyte- or Schwann cell-like) described for cultured primary OEC and TEG3 cells (Fig. 4f-i)(e.g., see also [24, 27], for details).

TEG3-generated $\mathrm{NgR}$ (Ecto) blocks Nogo66-AP binding to Nogo receptor

As indicated above, OECs and TEG3s express all members of the Nogo receptor complex (e.g., [24, 25, 59]). Thus, to determine whether the $\mathrm{NgR}$ (Ecto) produced by TEG3 cells was active, we incubated TEG3 cells $(\approx 75 \%$ confluence $)$ with Nogo66-AP in the absence or presence of $\mathrm{NgR}$ (Ecto)containing solution (Fig. 5a-e). After incubation, AP activity in treated cells was measured at $405 \mathrm{~nm}$ spectrophotometer (Fig. 5d, e). Results revealed a decrease of $\approx 18$ and $\approx 55 \%$ in the OD values after incubation with $150 \mathrm{nM}$ or $300 \mathrm{nM}$ TEG-produced $\mathrm{NgR}$ (Ecto) (Fig. 5e). In addition, we incubated with TEG3-generated NgR(Ecto) CGNs cultured on Poly-D-Lysine (Fig. 5f, g), as well as cell membranes of Mock- and NogoA-transfected HEK293 cells (Fig. 5f, g). Cultured CGNs were labelled using the TUJ-1 antibody. Neurite length of CGNs cultured over NogoA membranes was reduced to $\approx 40 \%$ compared to Mock-transfected and Poly-D-Lysine values (Fig. 5g) (Poly-D-Lys + Mock $=100.5 \pm 10.94 ;$ vs Membrane + Mock $=103 \pm 13.82$ vs NogoA Membrane + Mock $=$ $61.30 \pm 9.82$ ). This value reached $\mathrm{a} \approx 30 \%$ increase when cultured with $[150 \mathrm{mM}] \mathrm{NgR}$ (Ecto) (Fig. $5 \mathrm{~g}$ ) (NogoA Membrane $+\operatorname{Ngr}($ Ecto $)=85.43 \pm 13.01)$. The addition of $\mathrm{NgR}$ (Ecto) did not modify CGN neurite length
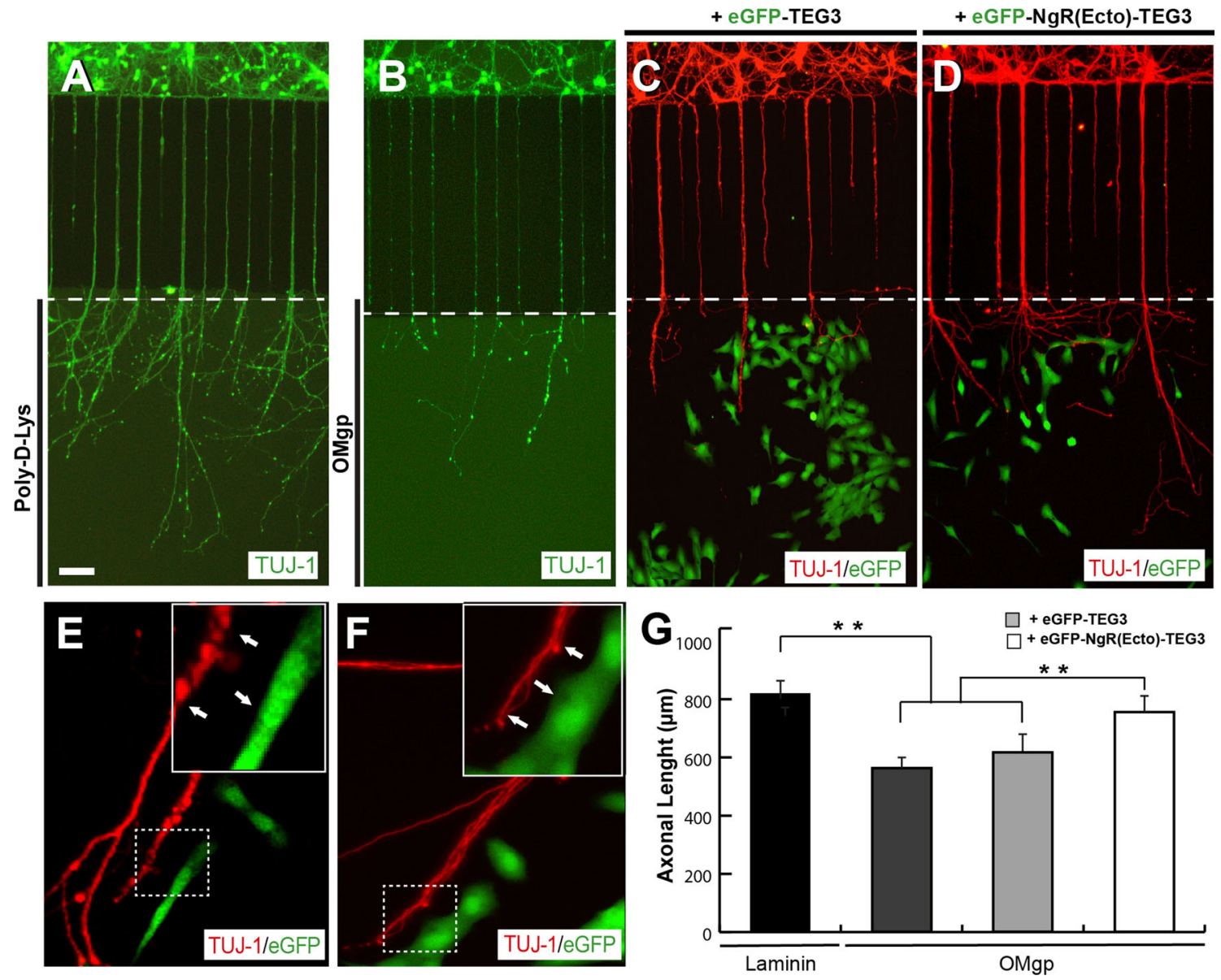

Fig. 6 Increased axonal growth of cortical neurons induced by eGFP$\mathrm{NgR}$ (Ecto)-TEG3 cells in microfluidic compartmentalized devices. a, b Photomicrographs illustrating examples of E15.5 cortical neurons cultured on Xona ${ }^{\mathrm{TM}}$ microfluidic devices coated with Poly-D-Lys (a) or OMgp (b) for 12 days (see Methods for details). c, d Examples of the combined co-culture of E15.5 cortical neurons and eGFP-TEG3 cells (c) or eGFP-NgR(Ecto)-TEG3 cells (d). After fixation, microfluidic devices were processed for TUJ-1 and eGFP immunostaining. e, f High power photomicrographs of doublelabelled microfluidic devices containing cortical axons (red) and

eGFP-NgR(Ecto)-TEG3 (green). Note that eGFP-NgR(Ecto)-TEG3 cells do not seem to be in contact with growing axons (arrows). $\mathbf{g}$ Histogram illustrating the quantitative results of the experiment illustrated in (a-d). The ends of the bridge channels are labelled by a white dashed line in (a-d). Data in (g) are represented as mean \pm S.E.M. Scale bars $a=100 \mu \mathrm{m}$ pertain to b-d. Asterisks in (g) indicate statistical differences (laminin vs OMgp $t=17.8$; laminin vs OMgp + eGFP-TEG3 $t=16.43$; OMgp + eGFP-TEG3 vs OMgp + eGFP- NgR(Ecto)-TEG3 $t=6.87 ; * * P<0.05$; one-way ANOVA Bonferroni post hoc test) 
when cultured over control HEK293 membranes (Membrane $+\operatorname{NgR}($ Ecto $) \quad 97.5 \pm 11.52$ vs Membrane + Mock $=103 \pm 13.82$ ).

$\mathrm{NgR}$ (Ecto)-TEG3 cells overcome OMgp inhibition to cortical axons in microfluidic platforms

Compartmentalized neuronal cultures of lab-on-a-chip devices have been used for different studies in recent years (see [60] for a recent review). Due to this specific design, media located in the axonal reservoir are unable to diffuse to the soma reservoir [61]. Thus, we aimed to determine whether $\mathrm{NgR}$ (Ecto)-TEG3 cells are able to stimulate axon outgrowth over inhibitory MAI-containing substrates (Fig. 6). Indeed, E15.5 cortical neurons cultured in one reservoir of the microfluidic platforms are able to cross the $900 \mu \mathrm{m}$ long bridge channels in one week to reach the recipient or axonal reservoir (Fig. 6a). In these conditions, cortical axons were able to spread in laminin-coated axonal reservoirs (Fig. 6a) expressing $\mathrm{NgR}$ receptor 3. Their axonal length was reduced by $\approx 25 \%$ when OMgp was present as substrate in the axonal reservoir (Fig. 6b). Next, we co-cultured eGFP-TEG3 and eGFP-Ngr(Ecto)-TEG3 cells in the axonal reservoir of parallel chips with E15.5 cortical neurons and coated with OMgp, as above (Fig. 6c, $\mathrm{d}, \mathrm{e}-\mathrm{g}$ ). Results indicated that eGFP-TEG3 was unable to statistically increase neurite length of cultured cortical neurons in the devices (Fig. 6c, g). In contrast, eGFP$\mathrm{NgR}$ (Ecto)-TEG3 cells were able to increase by $\approx 24 \%$ the axonal length of the cultured cortical neurons on OMgp (Fig. 6d, e-g) (up to $95 \%$ of the value obtained in the presence of laminin, Fig. $5 \mathrm{~g}$ ). However, we were unable to observe a clear interaction between cortical axons and eGFP-NgR(Ecto)-TEG3 cells in our microfluidic devices, suggesting that these positive effects were mediated by the secreted $\mathrm{NgR}$ (Ecto) in the axonal compartment (Fig. 6e, f).

Increased migration of $\mathrm{NgR}$ (Ecto)-TEG3 and $\mathrm{NgR}$ (Ecto)-treated TEG3 cells on MAI-coated substrates

Next we aimed to explore the migratory properties of $\mathrm{NgR}$ (Ecto)-TEG3 cells compared to TEG3 cells over inhibitory substrates and the specific effect of $\mathrm{NgR}$ (Ecto) on TEG3 cell migration over OMgp (Fig. 7). Indeed, TEG3 migration over laminin, myelin- and OMgp-coated substrates was monitored for $20 \mathrm{~h}$ in video time-lapse experiments as above. Quantitatively, in these experiments the migration speed of TEG3s cells over laminin was $0.79 \pm 0.05 \mu \mathrm{m} / \mathrm{min} \quad(n=38) \quad$ (Fig. 7c) $\quad$ and $0.82 \pm 0.04 \mu \mathrm{m} / \mathrm{min}(n=36)$ (Fig. 7f). In contrast, TEG3 cells growing over myelin- or OMgp-coated substrates showed a decrease in migrating speed $(0.3 \pm 0.04 \mu \mathrm{m} / \mathrm{min}$
(Myelin; $n=35)(0.24 \pm 0.02 \mu \mathrm{m} / \mathrm{min}(\mathrm{OMgp}, 10 \mu \mathrm{g} / \mathrm{ml}$; $n=35)$ as expected. $\mathrm{NgR}$ (Ecto)-TEG3 cells migrated as TEG3 cells over laminin $(0.79 \pm 0.05 \mu \mathrm{m} / \mathrm{min} ; n=38)$ (Fig. 7c) but with increased speed over myelin $(0.55 \pm 0.04 \mu \mathrm{m} / \mathrm{min} ; n=37)$ (Fig. 7c and Supplementary Movie 8) and OMgp $(0.47 \pm 0.02 \mu \mathrm{m} / \mathrm{min} ; n=36)$ (Fig. 7f and Supplementary Movie 9). In addition, when $\mathrm{NgR}$ (Ecto) was added to migrating TEG cells growing on OMgp-coated substrates, a 1.81-fold increase of the migratory speed was observed $[0.49 \pm 0.03 \mu \mathrm{m} / \mathrm{min} ; n=48$ (TEG3 $+\mathrm{NgR}$ (Ecto) $]$ and $0.27 \pm 0.02 \mu \mathrm{m} / \mathrm{min} ; n=37$ ) [TEG without $\mathrm{NgR}$ (Ecto)] (Fig. $7 \mathrm{~g}-1$ and Supplementary Movies 10,11). In addition, both TEG3 cells treated with $\mathrm{NgR}$ (Ecto) (Fig. 7k, n) and NgR(Ecto)-TEG3 cells (Fig. 7l, o) growing over OMgp displayed relevant filopodia (Fig. 7k, 1) with abundant puncta-like staining of vinculin, suggesting increased focal contacts (Fig. 7n, o) compared to parallel TEG cell cultures (Fig. 7j, m). In parallel, these data correlated with increased traction force on OMgp-coated treated with $\mathrm{NgR}$ (Ecto)-TEG3 $(0.00274 \pm 0.0006$, PJ; $n=25)$ and $\mathrm{NgR}$ (Ecto) $(0.00301 \pm 0.0005, \mathrm{PJ} ; n=28)$ (Fig. 8).

Increased migration of $\mathrm{NgR}$ (Ecto)-TEG3 cells in lesioned spinal cord

To further determine whether $\mathrm{NgR}$ (Ecto)-TEG3 cells also increased their migratory potential in vivo, 300,000 cells of eGFP- or $\mathrm{NgR}($ Ecto)-TEG3 were implanted in injured

Fig. 7 Enhanced $\mathrm{NgR}$ (Ecto)-TEG3 migration over myelin and OMgp. a-b Examples of TEGs cells (a, d) and NgR(Ecto)-TEG3 $(\mathbf{b}, \mathbf{e})$ migration on myelin- $(\mathbf{a}, \mathbf{b})$ and $\mathrm{OMgp}-(\mathbf{d}, \mathbf{e})$ coated glass substrates. The trajectory of selected cells is labelled by different colours. The quantification of the above illustrated experiments is plotted in (c) and (f). (g, h) Examples of the exogenous incubation with the effects of $\mathrm{NgR}$ (Ecto) on individual TEG3 migration on OMGp-coated glass substrates. The trajectory of selected TEG3 cells without $\mathrm{NgR}$ (Ecto) treatment is labelled in red in (g) and (h). Yellow lines show the changes observed after incubation with mock media (g) and $\mathrm{NgR}$ (Ecto) (h) in the selected cells. (i) Histogram showing the results of the time-lapse analysis and the effect of the $\mathrm{NgR}$ (Ecto) incubation on TEG3 cells. f-i Fluorescence photomicrographs of TEG3 (j, m), NgR(Ecto)-TEG3 cells (k, n), and TEG3 cells incubated with exogenous $\operatorname{NgR}($ Ecto) $(\mathbf{l}, \mathbf{o})$ immunoreacted to F-Actin $(\mathbf{j}-\mathbf{l})$ and vinculin $(\mathbf{m}-\mathbf{o})$ detection. All cells were growing over OMgp-coated substrates. Arrows in $(\mathbf{k}, \mathbf{l})$ and $(\mathbf{n}, \mathbf{o})$ point to stress fibres and vinculin-positive focal contacts, respectively. Scale bars: $a$ and $g=200 \mu \mathrm{m}$ pertain to $\mathrm{b}-\mathrm{e}$ and $\mathrm{h}$, respectively. $j$ and $m=50 \mu \mathrm{m}$ pertains to $(\mathbf{k}, \mathbf{l})$ and $(\mathbf{n}, \mathbf{o})$, respectively. Data (in $\mathbf{c}, \mathbf{f}$, and i) are represented by mean \pm s.e.m. Asterisks in (c, $\mathbf{f}$ and $\mathbf{i})$ indicate statistical differences $(* * P<0.05$, one-way ANOVA Bonferroni post hoc test). Results in c: laminin vs myelin (TEG3) $t=10.20$; laminin vs myelin (NgR(Ecto)-TEG3) $t=5.11$; myelin (TEG3) vs myelin (NgR(Ecto)-TEG3) $t=5.02$. Results in $\mathrm{f}$ : laminin vs OMgp $+(-$ TEG3) $t=13.56$; laminin vs OMgp $+(\mathrm{NgR}$ (Ecto)-TEG3) $t=8.35$; OMgp $+($ TEG3 $)$ vs OMgp $+($ NgR(Ecto $)-$ TEG3 $) t=5.21)$. Results in i: OMgp $+($ Pre-NgR(Ecto) vs OMgp $+(\mathrm{NgR}($ Ecto $)) t=7.58$ 

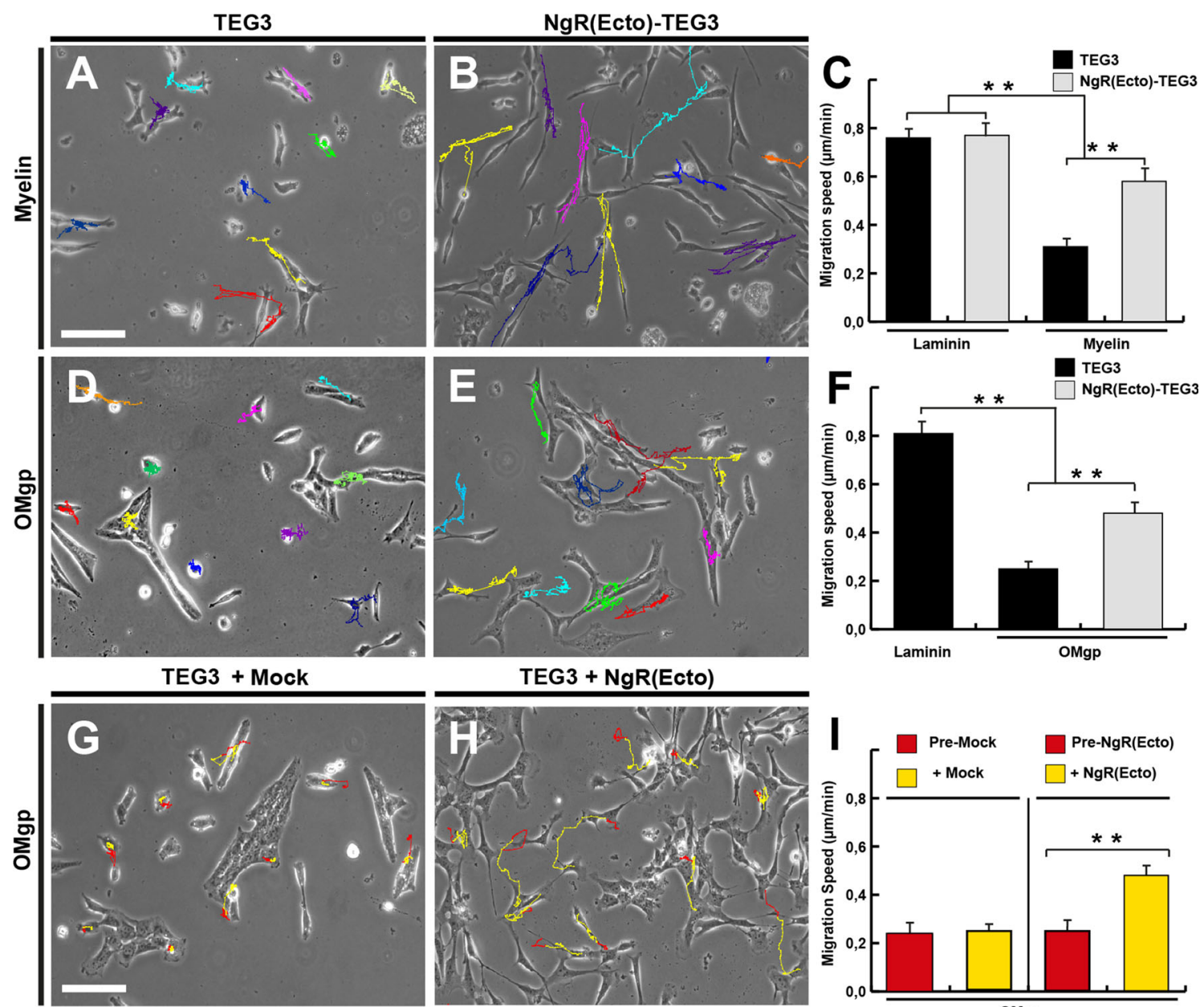

TEG3 + NgR(Ecto)
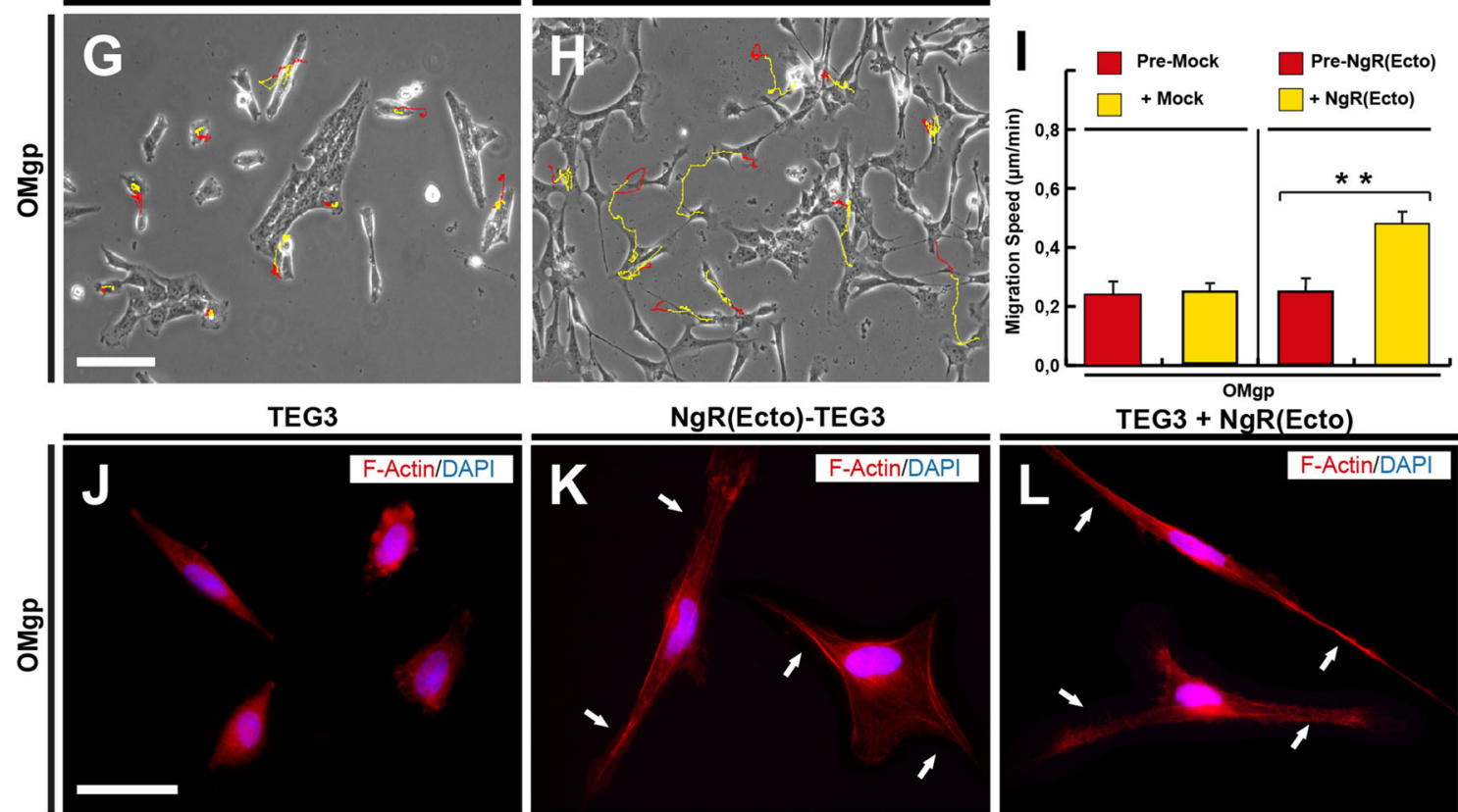

$\mathrm{NgR}$ (Ecto)-TEG3

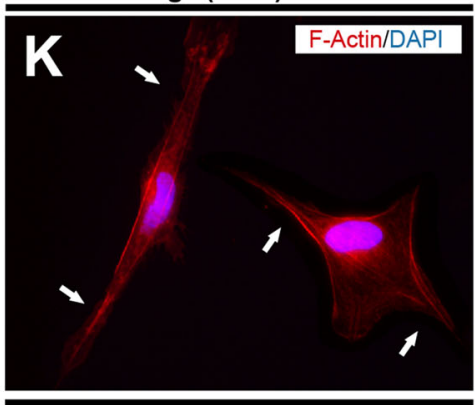

TEG3 + NgR(Ecto)
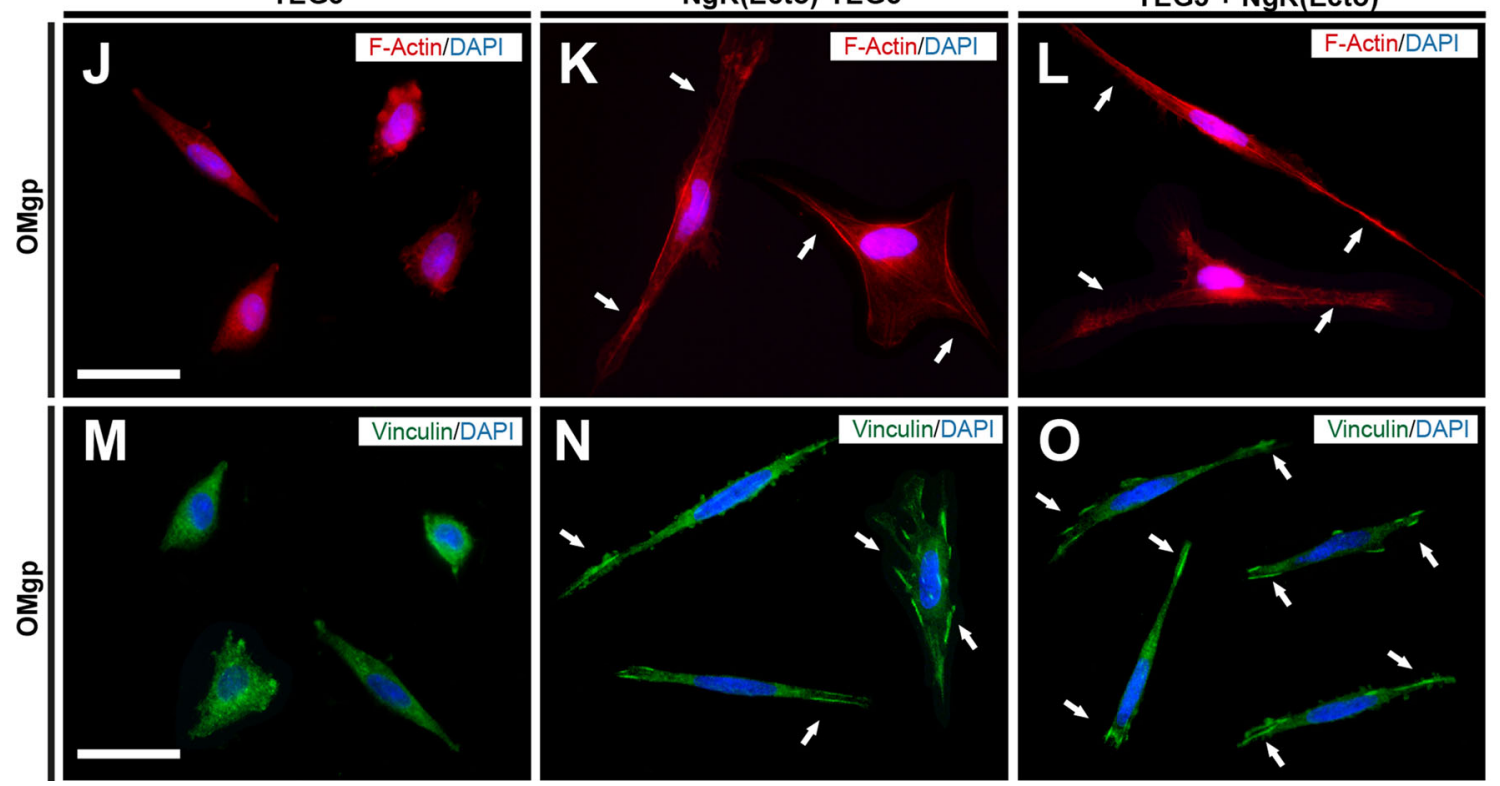


\section{NgR(Ecto)-TEG3-PAA-OMgp}

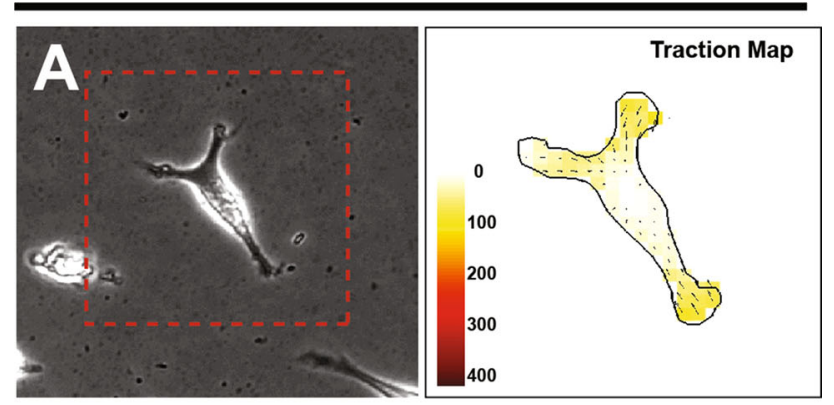

TEG3-PAA-OMgp + NgR(Ecto)
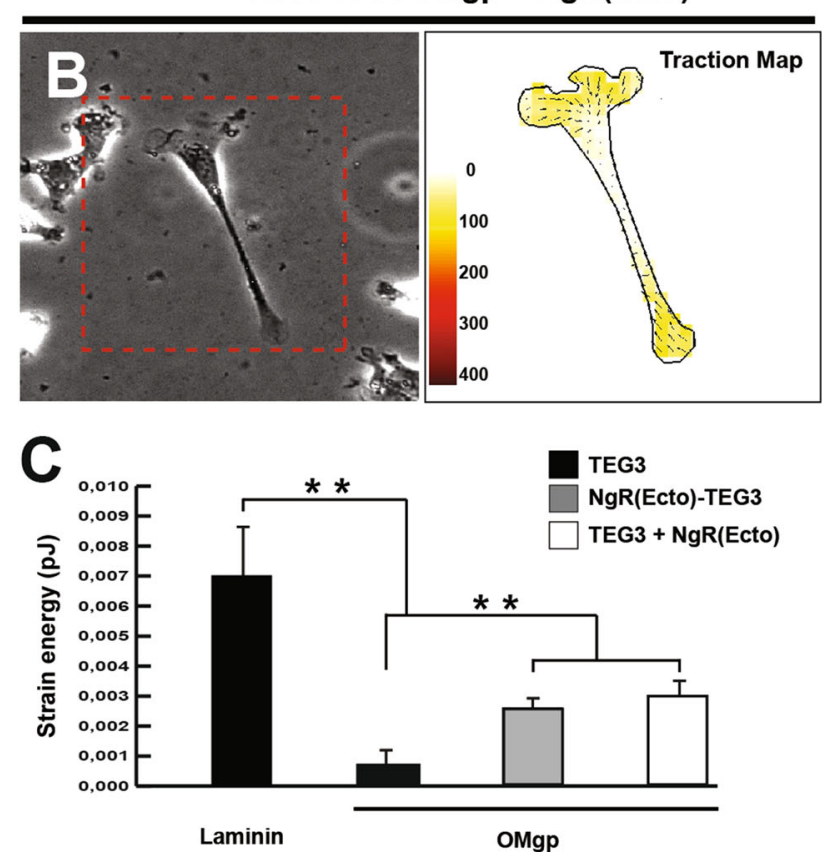

Fig. 8 Increased strain forces of $\mathrm{NgR}$ (Ecto)-TEG3 cells and TEG3 cells incubated with exogenous $\mathrm{NgR}$ (Ecto) in PAA gels coated with OMgp. a, b Quantitation of cellular traction forces of cultured $\mathrm{NgR}$ (Ecto)-TEG3 cells (a) and TEG3 cells + exogenous NgR(Ecto) (b) growing on PAA-OMgp gels. A phase contrast image of cultured cells is shown. The scale and the force map are also shown. Arrows indicate the direction of the bead displacement and the colour scale indicates the magnitude of the cellular traction force measured in $\mathrm{Pa}$ as in Fig. 2. (c) Histogram illustrating the quantitative results of the TFM analysis. Data in (c) are represented as mean \pm S.E.M. Asterisks in (c) indicate statistical differences $(* * P<0.05$, Bonferroni post hoc test); laminin + (TEG3) vs OMgp + (TEG3) $t=6.304$; laminin vs OMgp (NgR(Ecto)-TEG3) $t=4.93$; laminin vs OMgp $+[$ TEG3 $+\operatorname{NgR}($ Ecto $)] t=5.15$. OMgp $+($ TEG3) vs OMGp $+(\operatorname{NgR}($ Ecto $)-T E G 3) \quad t=5.02 ; \quad$ OMgp $+($ TEG3 $) \quad$ vs OMGp $+(\mathrm{NgR}$ (Ecto)-TEG3) $t=5.02$

spinal cords to analyse the capacity of these cells to integrate and migrate in the lesion model (Fig. 9). A total of 6 rats were used ( 3 rats received eGFP-TEG3 cells, and the other 3 eGFP/NgR(Ecto)-TEG3). A week after transplantation, spinal cords were perfusion fixed and the localization and distribution of eGFP-positive cells were analysed (see Method for details). Eight representative slices were selected for analysis for each animal. The total number of eGFP-positive cells in the case of eGFP-TEG3s $(6000 \pm 250$ cells/slice $)$ was slightly less than that of eGFP-NgR(Ecto)-TEG3s $\quad(7000 \pm 200$ cells/slice $) . \quad$ To assess the distance migrated, we counted the number of eGFP-positive cells in transversal stripe of about $200 \mu \mathrm{m}$ in length starting from the injection point. Eleven lines or stripe caudal or rostral to the injection points were analysed (Fig. 8a, c, e). Results revealed that most eGFP-TEG3 s were distributed near the injection point with the maximum cell percentage $(\approx 25 \%)$ found in the section $400 \mu \mathrm{m}$ rostral or caudal to these points (Fig. 9b, c, h). Moreover, very few eGFP-TEG3 cells were observed more than $1,600-1,800 \mu \mathrm{m}$ from the injection point $(\approx 8-9$ stripe; Fig. 9h). By contrast, eGFP-NgR(Ecto)-TEG3 cells were found in all 11 stripes analysed (Fig. 9d, e, h) with a plateau in the number of cells (around 13-16\%) found in the first four sections $(\approx 800 \mu \mathrm{m})$ rostral or caudal to the injection points decreasing slowly in the following stripes (Fig. 9h). In addition, increased numbers of eGFPNgR(Ecto)-TEG3 cells were also observed on the lesion side (Fig. 9f, g).

\section{Discussion}

In physiological conditions, the migration of most cells occurs in an adhesion-dependent manner and involves the formation of $\mathrm{FA}$ at the membrane and the generation of mechanical forces via the actin-myosin network [62]. Traction force comes into play in the synchronization of these processes in different cell types (e.g., keratinocytes [62], invasive tumor cells [63], fibroblasts [64, 65]) and olfactory ensheathing cells ([24] and present results). Thus, the balance between traction force and adhesion strength can be understood as a direct indicator of cell migration capacity. Using TFM and single cell tracking, we showed the behaviour of TEG3 cells in a quantitative basis demonstrating that the increased traction force is sufficient to tilt the mechanical balance toward a pro-migratory phenotype of OECs [24].

CSPGs as well as MAIs and their receptors modulate the establishment of this actin-myosin network as well as microtubule dynamics [5, 66]. Indeed, MAI-induced arrest of CNS axon growth is either induced after MAI receptor, the $\mathrm{Ca}^{2+}$-dependent activation of the epidermal growth factor receptor (EGFr), or induced by sequential RhoA/ RhoK/LIM-kinase/cofilin phosphorylation, leading to actin depolymerization [67]. In parallel, microtubule stabilization is also compromised after exposure to MAIs [68]. Our results reinforce the notion that molecules present in myelin extracts act on Nogo receptor complex as well as on 

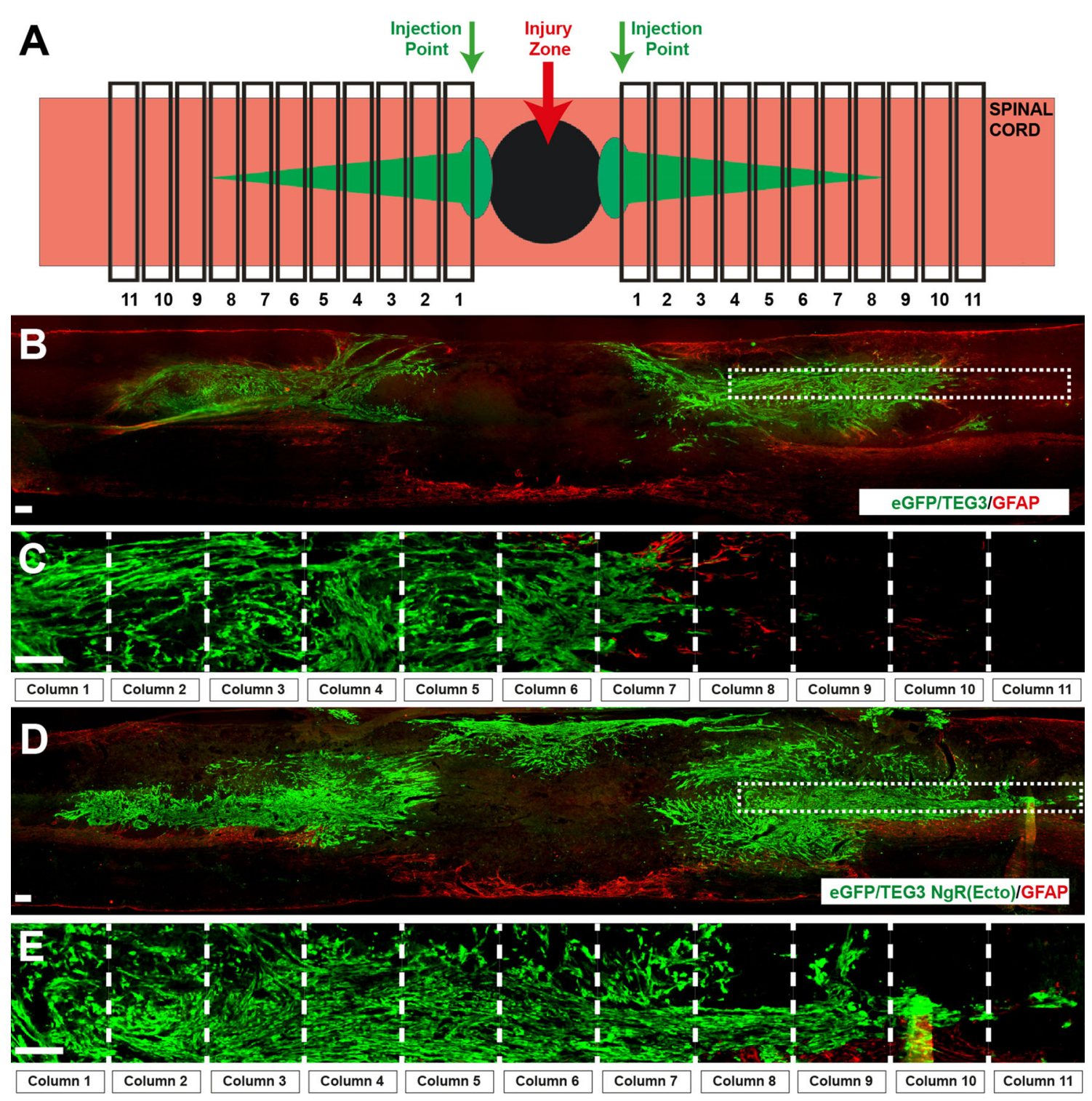
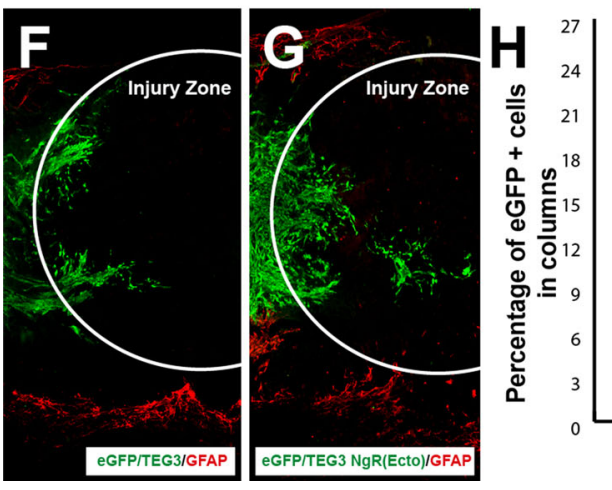

Fig. 9 Enhanced migration of eGFP-NgR(Ecto) into contused spinal cord. a Scheme of the experimental procedure. b-e Examples of longitudinal sections of the lesioned spinal cord transplanted with eGFP-TEG3 (b, c) or eGFP-NgR(Ecto). TEG3 (d, e) cells immunoreacted to GFAP and eGFP. The boxed areas in (b) and (d) are shown in (c) and (e), respectively. The 11 columns are indicated in each case. (f, g) Medium power photomicrographs illustrating eGFP-TEG3 (f) and eGFP-NgR(Ecto)-TEG3 (g) cells at the contused lesion site. $\mathbf{h}$ Histogram illustrating the quantitative results of the experiment illustrated in $(\mathbf{b}-\mathbf{e})$. Data in $(\mathbf{h})$ are represented as mean \pm S.E.M. of the percentage of eGFP labelled cells in each column. Scale bars b$\mathrm{e}=100 \mu \mathrm{m}$ 
other receptors, and may modulate OEC cytoskeleton and FA distribution.

OEC transplantation has been shown to promote regeneration and functional recovery in lesioned spinal cord $[9,10]$. In that the regenerative properties of OECs are largely associated with their migration and lamellipodial dynamics (e.g., [23, 69]) there is a considerable interest in enhancing OEC migratory capacity. In fact, it is assumed that OECs migrate ahead of growing axons and by secreting supporting factors (e.g., GDNF) [16, 28], or with matrix metalloproteinase activity [70] aiding and promoting their elongation. These positive effects on axon elongation have also been described for DRG cells cultured on myelin in the presence of OECs (e.g., secreting BDNF) [28]. In a previous study, we demonstrated that OECs express the $\mathrm{NgR}$ receptor complex (NgR1, P75, Lingo1 and TROY) and that their migration is also impaired by myelin [24]. In addition, NogoA, Slit2, and fibulin-3 have been reported as inhibitors of OEC migration. However, the effects of CSPG on OEC migration have not been previously studied. Here, we described how CSPGs largely impair OEC migration by reducing the mechanical strain force that cells transmit to the coated substrate. This reduced force correlates well with the low number of vinculine-positive focal contacts and profound reorganization of F-Actin cortical cytoskeleton. In fact, a recent study described how CSPGs are also ligands for NgR1 and NgR3 MAI receptors [71]. TEG3 and NgR(Ecto)-TEG3 cells express NgR1 ([24] and present results), which may explain some of the observed results that point to a functional redundancy between myelin inhibitors and CSPGs blocking OEC migration. However, because the binding region of CSPG to NgR1 is located in the Stalk region of the receptor, no relevant changes were observed between $\mathrm{NgR}$ (Ecto)-TEG3 and TEG3 cell migration over CSPG)(not shown).

Present results also reinforce the notion that most of the factors inhibiting axon elongation and regrowth after lesion may also affect OEC migration. In fact, to date all the described molecules inhibiting OEC migration-NogoA, fibulin-3, and Slit2-have been reported to be overexpressed in CNS scars after lesion [31, 72, 73]. Thus, in this scenario it is reasonable to consider that the combined treatment developed by Fouad et al, with ChABC, Schwann cell bridges, and OEC transplantation, may positively affect both OEC migration and axon regrowth [32]. Furthermore, secreted semaphorins (e.g., Sema3A) are expressed by OECs [74] and seem not to affect migration of OECs (J.A.D.R. unpublished results). In this respect, the single genetic ablation of MAIs [75] alone or with semaphorin receptors [76] is not strong enough to support axon regrowth after SCI. In contrast, it seems that blocking the MAI receptors $\mathrm{NgR} 1$ and
$\mathrm{NgR} 3$ and CSPG receptors yields better results [71]. In light of the foregoing, we consider that a transplantation strategy with cells with endogenous neurotrophic support (producing GDNF or BDNF) and enhanced migratory properties in parallel with pharmacological treatment should be strongly considered as a potential combined therapy for SCI lesion. Indeed, in the present study we genetically modified TEG3 to express a soluble form of NgR1 receptor to overcome myelin-derived inhibition [36]. Results demonstrate that $\mathrm{NgR}$ (Ecto)-TEG3 cells migrate faster in vitro over OMgp and myelin-coated substrates in vivo as well after contusive lesions of the spinal cord. In addition, the recovery of migration capacity correlates with increased traction force observed in TFM experiments in $\mathrm{NgR}$ (Ecto)-TEG3s cells. However, the two recoveries (migration and strain forces) are not complete, suggesting that other factors are involved in this inhibition. Indeed, OECs might respond to other myelin-associated molecules (e.g., lipids [77]) or express receptors other than $\mathrm{NgR} 1$ (e.g., LDL, receptor related protein 1) [78], which could exert inhibitory action on axonal growth. However, whether these lipids could act on OECs is unknown and warrants further study. Yet another challenging question remains unsolved since $\mathrm{NgR}$ (Ecto)-TEG3 presents random migration as described for normal TEG3, which suggests that other strategies may be needed to generate a persistent and directed migration in the lesioned spinal cord using directed chemoattraction [24, 79] on specific functionalized biomaterials [80, 81]. In conclusion, we have demonstrated that OEC migration is impaired by CSPG and that an engineered OEC cell line to produce $\mathrm{NgR}$ ectodomain abolished the inhibitory properties of myelin extract and purified OMgp. These effects also correlate with increased migration after in vivo transplantation in contused spinal cord. Future experiments will be directed to overcoming CSPG inhibition in engineered cells to enhanced functional axon regeneration after lesion.

Acknowledgments The authors thank Tom Yohannan for editorial advice and Oscar Castaño, Miguel Ángel Mateos-Timoneda and E. Engel for helping in S.E.M studies and offering comments on the manuscript. We also thank M. Segura and M. Morell for technical assistance, and members of the Del Río, Samitier and Trepat laboratories for stimulating discussions and ideas. This research was supported by the Spanish Ministry of Science and Innovation (BFU2012-32617), the Generalitat de Catalunya (SGR2014-1218), La Caixa Obra Social Foundation, and the Basque Foundation of Health and Innovation Research (BIO12/AL/ 004) to JADR. RG was supported by Fondo de Investigaciones Sanitarias (PI11-00075) and work in FW's lab was supported by grants from the Dirección General de Ciencia y TecnologiaDGCYT-(SAF2012-39148-C03-01), and EU-FP7-2009-(CT222887), as well as an institutional grant from the 'Fundación Areces'. Work at XN's lab was supported by grants from the Spanish Ministry of Science and Innovation (SAF2009-12495), and funds from 
CIBERNED and Cell Therapy Network (TERCEL) of the Instituto de Salud Carlos III of Spain. XT was supported by the Spanish Ministry of Economy and Competitiveness (BFU2012-38146) and the European Research Council (Grant Agreement 242993). JS was supported by the Fundación Botín and Institute Salud Carlos III PI10/01171. PC was supported by AGAUR, and SN and OS were supported by MINECO and IBEC. DR was supported by a fellowship from the National Commission for Science and Technology (CONICYT, Chile) and A. M-A was supported by a fellowship from the Fundación Tatiana Pérez de Guzmán el Bueno.

\section{References}

1. Dumont RJ, Okonkwo DO, Verma S, Hurlbert RJ, Boulos PT, Ellegala DB, Dumont AS (2001) Acute spinal cord injury, part I: pathophysiologic mechanisms. Clin Neuropharmacol 24(5):254-264

2. Furlan JC, Sakakibara BM, Miller WC, Krassioukov AV (2013) Global incidence and prevalence of traumatic spinal cord injury. Can J Neurol Sci 40(4):456-464 (H20571742RW34510)

3. Yang XF, Wang H, Wen L (2011) From myelin debris to inflammatory responses: a vicious circle in diffuse axonal injury. Med Hypotheses 77(1):60-62. doi:10.1016/j.mehy.2011.03.023

4. Yiu G, He Z (2006) Glial inhibition of CNS axon regeneration. Nat Rev Neurosci 7(8):617-627. doi:10.1038/nrn1956

5. Llorens F, Gil V, del Rio JA (2011) Emerging functions of myelin-associated proteins during development, neuronal plasticity, and neurodegeneration. FASEB J 25(2):463-475. doi:10. 1096/fj.10-162792

6. Wang H, Fang H, Dai J, Liu G, Xu ZJ (2013) Induced pluripotent stem cells for spinal cord injury therapy: current status and perspective. Neurol Sci 34(1):11-17. doi:10.1007/s10072-012-11453

7. Sun Y, Xu CC, Li J, Guan XY, Gao L, Ma LX, Li RX, Peng YW, Zhu GP (2013) Transplantation of oligodendrocyte precursor cells improves locomotion deficits in rats with spinal cord irradiation injury. PLoS One 8(2):e57534. doi:10.1371/journal.pone. 0057534PONE-D-12-27814

8. Li Y, Li D, Raisman G (2005) Interaction of olfactory ensheathing cells with astrocytes may be the key to repair of tract injuries in the spinal cord: the 'pathway hypothesis'. J Neurocytol 34(3-5):343-351. doi:10.1007/s11068-005-8361-1

9. Roet KC, Verhaagen J (2014) Understanding the neural repairpromoting properties of olfactory ensheathing cells. Exp Neurol. doi:10.1016/j.expneurol.2014.05.007

10. Raisman G, Barnett SC, Ramon-Cueto A (2012) Repair of central nervous system lesions by transplantation of olfactory ensheathing cells. Handb Clin Neurol 109:541-549. doi:10.1016/B978-0444-52137-8.00033-4

11. Doucette JR, Kiernan JA, Flumerfelt BA (1983) The re-innervation of olfactory glomeruli following transection of primary olfactory axons in the central or peripheral nervous system. J Anat 137(Pt 1):1-19

12. Nedelec S, Dubacq C, Trembleau A (2005) Morphological and molecular features of the mammalian olfactory sensory neuron axons: what makes these axons so special? J Neurocytol 34(1-2):49-64. doi:10.1007/s11068-005-5047-7

13. Ramon-Cueto A, Santos-Benito FF (2001) Cell therapy to repair injured spinal cords: olfactory ensheathing glia transplantation. Restor Neurol Neurosci 19(1-2):149-156

14. Lu J, Feron F, Mackay-Sim A, Waite PM (2002) Olfactory ensheathing cells promote locomotor recovery after delayed transplantation into transected spinal cord. Brain 125(Pt 1):14-21
15. Lopez-Vales R, Fores J, Navarro X, Verdu E (2006) Olfactory ensheathing glia graft in combination with FK506 administration promote repair after spinal cord injury. Neurobiol Dis 24(3):443-454. doi:10.1016/j.nbd.2006.08.001

16. Ekberg JA, Amaya D, Mackay-Sim A, St John JA (2012) The migration of olfactory ensheathing cells during development and regeneration. Neuro-Signals 20(3):147-158. doi:10.1159/ 000330895

17. Ramon-Cueto A, Plant GW, Avila J, Bunge MB (1998) Longdistance axonal regeneration in the transected adult rat spinal cord is promoted by olfactory ensheathing glia transplants. J Neurosci 18(10):3803-3815

18. Resnick DK, Cechvala CF, Yan Y, Witwer BP, Sun D, Zhang S (2003) Adult olfactory ensheathing cell transplantation for acute spinal cord injury. J Neurotrauma 20(3):279-285. doi:10.1089/ 089771503321532860

19. Lu P, Yang H, Culbertson M, Graham L, Roskams AJ, Tuszynski MH (2006) Olfactory ensheathing cells do not exhibit unique migratory or axonal growth-promoting properties after spinal cord injury. J Neurosci 26(43):11120-11130. doi:10.1523/ JNEUROSCI.3264-06.2006

20. Deng C, Gorrie C, Hayward I, Elston B, Venn M, Mackay-Sim A, Waite P (2006) Survival and migration of human and rat olfactory ensheathing cells in intact and injured spinal cord. J Neurosci Res 83(7):1201-1212. doi:10.1002/jnr.20817

21. Cao L, Su Z, Zhou Q, Lv B, Liu X, Jiao L, Li Z, Zhu Y, Huang Z, Huang A, He C (2006) Glial cell line-derived neurotrophic factor promotes olfactory ensheathing cells migration. Glia 54(6):536-544. doi:10.1002/glia.20403

22. Huang ZH, Wang Y, Su ZD, Geng JG, Chen YZ, Yuan XB, He C (2011) Slit-2 repels the migration of olfactory ensheathing cells by triggering $\mathrm{Ca}^{2+}$ - dependent cofilin activation and RhoA inhibition. J Cell Sci 124(Pt 2):186-197. doi:10.1242/jcs.071357

23. Wang Y, Huang ZH (2012) Morphological phenotypes of olfactory ensheathing cells display different migratory responses upon Slit-2. Exp Cell Res 318(15):1889-1900. doi:10.1016/j. yexcr.2012.05.024

24. Nocentini S, Reginensi D, Garcia S, Carulla P, Moreno-Flores MT, Wandosell F, Trepat X, Bribian A, del Rio JA (2012) Myelin-associated proteins block the migration of olfactory ensheathing cells: an in vitro study using single-cell tracking and traction force microscopy. Cell Mol Life Sci 69(10):1689-1703. doi:10.1007/s00018-011-0893-1

25. Su Z, Cao L, Zhu Y, Liu X, Huang Z, Huang A, He C (2007) Nogo enhances the adhesion of olfactory ensheathing cells and inhibits their migration. J Cell Sci 120(Pt 11):1877-1887. doi:10. $1242 /$ jcs. 03448

26. Vukovic J, Ruitenberg MJ, Roet K, Franssen E, Arulpragasam A, Sasaki T, Verhaagen J, Harvey AR, Busfield SJ, Plant GW (2009) The glycoprotein fibulin-3 regulates morphology and motility of olfactory ensheathing cells in vitro. Glia 57(4):424-443. doi:10. 1002/glia.20771

27. Riggio C, Nocentini S, Catalayud MP, Goya GF, Cuschieri A, Raffa V, Del Rio JA (2013) Generation of magnetized olfactory ensheathing cells for regenerative studies in the central and peripheral nervous tissue. Int J Mol Sci 14(6):10852-10868. doi:10. 3390/ijms 140610852

28. Runyan SA, Phelps PE (2009) Mouse olfactory ensheathing glia enhance axon outgrowth on a myelin substrate in vitro. Exp Neurol 216(1):95-104. doi:10.1016/j.expneurol.2008.11.015

29. Silver J, Miller JH (2004) Regeneration beyond the glial scar. Nat Rev Neurosci 5(2):146-156. doi:10.1038/nrn1326

30. Fawcett JW, Schwab ME, Montani L, Brazda N, Muller HW (2012) Defeating inhibition of regeneration by scar and myelin components. Handb Clin Neurol 109:503-522. doi:10.1016/ B978-0-444-52137-8.00031-0 
31. Cregg JM, DePaul MA, Filous AR, Lang BT, Tran A, Silver J (2014) Functional regeneration beyond the glial scar. Exp Neurol 253:197-207. doi:10.1016/j.expneurol.2013.12.024

32. Fouad K, Schnell L, Bunge MB, Schwab ME, Liebscher T, Pearse DD (2005) Combining Schwann cell bridges and olfactory-ensheathing glia grafts with chondroitinase promotes locomotor recovery after complete transection of the spinal cord. J Neurosci 25(5):1169-1178. doi:10.1523/JNEUROSCI.3562-04. 2005

33. Fouad K, Pearse DD, Tetzlaff W, Vavrek R (2009) Transplantation and repair: combined cell implantation and chondroitinase delivery prevents deterioration of bladder function in rats with complete spinal cord injury. Spinal Cord 47(10):727-732. doi:10. 1038/sc.2009.10

34. Del Rio JA, Soriano E (2007) Overcoming chondroitin sulphate proteoglycan inhibition of axon growth in the injured brain: lessons from chondroitinase ABC. Curr Pharm Des 13(24):2485-2492

35. Moreno-Flores MT, Lim F, Martin-Bermejo MJ, Diaz-Nido J, Avila J, Wandosell F (2003) Immortalized olfactory ensheathing glia promote axonal regeneration of rat retinal ganglion neurons. J Neurochem 85(4):861-871

36. Fournier AE, Gould GC, Liu BP, Strittmatter SM (2002) Truncated soluble Nogo receptor binds Nogo-66 and blocks inhibition of axon growth by myelin. J Neurosci 22(20):8876-8883 (22/20/ 8876)

37. He XL, Bazan JF, McDermott G, Park JB, Wang K, TessierLavigne M, He Z, Garcia KC (2003) Structure of the Nogo receptor ectodomain: a recognition module implicated in myelin inhibition. Neuron 38(2):177-185 (S0896627303002320)

38. Li S, Liu BP, Budel S, Li M, Ji B, Walus L, Li W, Jirik A, Rabacchi S, Choi E, Worley D, Sah DW, Pepinsky B, Lee D, Relton J, Strittmatter SM (2004) Blockade of Nogo-66, myelinassociated glycoprotein, and oligodendrocyte myelin glycoprotein by soluble Nogo-66 receptor promotes axonal sprouting and recovery after spinal injury. J Neurosci 24(46):10511-10520. doi:10.1523/JNEUROSCI.2828-04.2004

39. Wang X, Baughman KW, Basso DM, Strittmatter SM (2006) Delayed Nogo receptor therapy improves recovery from spinal cord contusion. Ann Neurol 60(5):540-549. doi:10.1002/ana. 20953

40. Seira O, Gavin R, Gil V, Llorens F, Rangel A, Soriano E, del Rio JA (2010) Neurites regrowth of cortical neurons by GSK3beta inhibition independently of Nogo receptor 1 . J Neurochem 113(6):1644-1658. doi:10.1111/j.1471-4159.2010.06726.x

41. Mingorance A, Fontana X, Sole M, Burgaya F, Urena JM, Teng FY, Tang BL, Hunt D, Anderson PN, Bethea JR, Schwab ME, Soriano E, del Rio JA (2004) Regulation of Nogo and Nogo receptor during the development of the entorhino-hippocampal pathway and after adult hippocampal lesions. Mol Cell Neurosci 26(1):34-49. doi:10.1016/j.mcn.2004.01.001

42. Montolio M, Messeguer J, Masip I, Guijarro P, Gavin R, Antonio Del Rio J, Messeguer A, Soriano E (2009) A semaphorin 3A inhibitor blocks axonal chemorepulsion and enhances axon regeneration. Chem Biol 16(7):691-701. doi:10.1016/j.chembiol. 2009.05.006

43. Niederost B, Oertle T, Fritsche J, McKinney RA, Bandtlow CE (2002) Nogo-A and myelin-associated glycoprotein mediate neurite growth inhibition by antagonistic regulation of RhoA and Rac1. J Neurosci 22(23):10368-10376

44. Taylor AM, Blurton-Jones M, Rhee SW, Cribbs DH, Cotman CW, Jeon NL (2005) A microfluidic culture platform for CNS axonal injury, regeneration and transport. Nat Methods 2(8):599-605. doi:10.1038/nmeth777

45. Butler JP, Tolic-Norrelykke IM, Fabry B, Fredberg JJ (2002) Traction fields, moments, and strain energy that cells exert on their surroundings. Am J Physiol Cell Physiol 282(3):C595C605. doi:10.1152/ajpcell.00270.2001

46. Trepat X, Wasserman MR, Angelini TE, Millet E, Weitz DA, Butler JP, Fredberg JJ (2009) Physical forces during collective cell migration. Nat Phys 5 (6):426-430. doi:http://www.nature. com/nphys/journal/v5/n6/suppinfo/nphys1269_S1.html

47. Windus LC, Claxton C, Allen CL, Key B, St John JA (2007) Motile membrane protrusions regulate cell-cell adhesion and migration of olfactory ensheathing glia. Glia 55(16):1708-1719. doi:10.1002/glia.20586

48. Windus LC, Lineburg KE, Scott SE, Claxton C, Mackay-Sim A, Key B, St John JA (2010) Lamellipodia mediate the heterogeneity of central olfactory ensheathing cell interactions. Cell Mol Life Sci 67(10):1735-1750. doi:10.1007/s00018-010-0280-3

49. Roca-Cusachs P, Sunyer R, Trepat X (2013) Mechanical guidance of cell migration: lessons from chemotaxis. Curr Opin Cell Biol 25(5):543-549. doi:10.1016/j.ceb.2013.04.010

50. Trepat X, Chen Z, Jacobson K (2012) Cell migration. Comprehensive. Physiology 2(4):2369-2392. doi:10.1002/cphy.c110012

51. Tambe DT, Croutelle U, Trepat X, Park CY, Kim JH, Millet E, Butler JP, Fredberg JJ (2013) Monolayer stress microscopy: limitations, artifacts, and accuracy of recovered intercellular stresses. PLoS One 8(2):e55172. doi:10.1371/journal.pone.0055172

52. McKeon RJ, Hoke A, Silver J (1995) Injury-induced proteoglycans inhibit the potential for laminin-mediated axon growth on astrocytic scars. Exp Neurol 136(1):32-43. doi:10.1006/exnr.1995.1081

53. Mountney A, Zahner MR, Sturgill ER, Riley CJ, Aston JW, Oudega M, Schramm LP, Hurtado A, Schnaar RL (2013) Sialidase, chondroitinase $\mathrm{ABC}$, and combination therapy after spinal cord contusion injury. J Neurotrauma 30(3):181-190. doi:10. 1089/neu.2012.2353

54. Bradbury EJ, Moon LD, Popat RJ, King VR, Bennett GS, Patel PN, Fawcett JW, McMahon SB (2002) Chondroitinase ABC promotes functional recovery after spinal cord injury. Nature 416(6881):636-640. doi:10.1038/416636a

55. Bradbury EJ, Carter LM (2011) Manipulating the glial scar: chondroitinase $\mathrm{ABC}$ as a therapy for spinal cord injury. Brain Res Bull 84(4-5):306-316. doi:10.1016/j.brainresbull.2010.06.015

56. Zhang C, He X, Lan B, Li H (2009) Study on repair of subacute spinal cord injury by transplantation of olfactory ensheathing cells combined with chondroitinase $\mathrm{ABC}$ in adult rats. Zhongguo Xiu Fu Chong Jian Wai Ke Za Zhi 23(1):8-13

57. Kanno H, Pressman Y, Moody A, Berg R, Muir EM, Rogers JH, Ozawa H, Itoi E, Pearse DD, Bunge MB (2014) Combination of engineered Schwann cell grafts to secrete neurotrophin and chondroitinase promotes axonal regeneration and locomotion after spinal cord injury. J Neurosci 34(5):1838-1855. doi:10. 1523/JNEUROSCI.2661-13.2014

58. Cafferty WB, Yang SH, Duffy PJ, Li S, Strittmatter SM (2007) Functional axonal regeneration through astrocytic scar genetically modified to digest chondroitin sulfate proteoglycans. J Neurosci 27(9):2176-2185. doi:10.1523/JNEUROSCI.5176-06. 2007

59. Woodhall E, West AK, Vickers JC, Chuah MI (2003) Olfactory ensheathing cell phenotype following implantation in the lesioned spinal cord. Cell Mol Life Sci 60(10):2241-2253. doi:10. 1007/s00018-003-3265-7

60. Park JW, Kim HJ, Kang MW, Jeon NL (2013) Advances in microfluidics-based experimental methods for neuroscience research. Lab Chip 13(4):509-521. doi:10.1039/c2lc41081h

61. Taylor AM, Rhee SW, Tu CH, Cribbs DH, Cotman CW, Jeon NL (2003) Microfluidic multicompartment device for neuroscience research. Langmuir 19(5):1551-1556. doi:10.1021/la026417v

62. Fournier MF, Sauser R, Ambrosi D, Meister JJ, Verkhovsky AB (2010) Force transmission in migrating cells. J Cell Biol 188(2):287-297. doi:10.1083/jcb.200906139 
63. Mierke CT, Rosel D, Fabry B, Brabek J (2008) Contractile forces in tumor cell migration. Eur J Cell Biol 87(8-9):669-676. doi:10. 1016/j.ejcb.2008.01.002

64. Wang HB, Dembo M, Hanks SK, Wang Y (2001) Focal adhesion kinase is involved in mechanosensing during fibroblast migration. Proc Natl Acad Sci USA 98(20):11295-11300. doi:10.1073/pnas. 20120119898/20/11295

65. Li S, Guan JL, Chien S (2005) Biochemistry and biomechanics of cell motility. Annu Rev Biomed Eng 7:105-150. doi:10.1146/ annurev.bioeng.7.060804.100340

66. Schwab ME (2010) Functions of Nogo proteins and their receptors in the nervous system. Nat Rev Neurosci 11(12):799-811. doi:10.1038/nrn2936

67. Hsieh SH, Ferraro GB, Fournier AE (2006) Myelin-associated inhibitors regulate cofilin phosphorylation and neuronal inhibition through LIM kinase and Slingshot phosphatase. J Neurosci 26(3):1006-1015. doi:10.1523/JNEUROSCI.2806-05.2006

68. Mimura F, Yamagishi S, Arimura N, Fujitani M, Kubo T, Kaibuchi K, Yamashita T (2006) Myelin-associated glycoprotein inhibits microtubule assembly by a Rho-kinase-dependent mechanism. J Biol Chem 281(23):15970-15979. doi:10.1074/jbc. M510934200

69. Roloff F, Ziege S, Baumgartner W, Wewetzer K, Bicker G (2013) Schwann cell-free adult canine olfactory ensheathing cell preparations from olfactory bulb and mucosa display differential migratory and neurite growth-promoting properties in vitro. BMC Neurosci 14:141. doi:10.1186/1471-2202-14-141

70. Ould-Yahoui A, Sbai O, Baranger K, Bernard A, Gueye Y, Charrat E, Clement B, Gigmes D, Dive V, Girard SD, Feron F, Khrestchatisky M, Rivera S (2013) Role of matrix metalloproteinases in migration and neurotrophic properties of nasal olfactory stem and ensheathing cells. Cell Transplant 22(6):993-1010. doi:10.3727/096368912X657468

71. Dickendesher TL, Baldwin KT, Mironova YA, Koriyama Y, Raiker SJ, Askew KL, Wood A, Geoffroy CG, Zheng B, Liepmann CD, Katagiri Y, Benowitz LI, Geller HM, Giger RJ (2012) $\mathrm{NgR} 1$ and NgR3 are receptors for chondroitin sulfate proteoglycans. Nat Neurosci 15(5):703-712. doi:10.1038/nn.3070

72. Lukovic D, Valdes-Sanchez L, Sanchez-Vera I, Moreno-Manzano V, Stojkovic M, Bhattacharya SS, Erceg S (2014) Brief report: astrogliosis promotes functional recovery of completely transected spinal cord following transplantation of hESC-derived oligodendrocyte and motoneuron progenitors. Stem Cells 32(2):594-599. doi:10.1002/stem.1562

73. Vukovic J, Marmorstein LY, McLaughlin PJ, Sasaki T, Plant GW, Harvey AR, Ruitenberg MJ (2009) Lack of fibulin-3 alters regenerative tissue responses in the primary olfactory pathway. Matrix Biol 28(7):406-415. doi:10.1016/j.matbio.2009.06.001

74. Schwarting GA, Kostek C, Ahmad N, Dibble C, Pays L, Puschel AW (2000) Semaphorin 3A is required for guidance of olfactory axons in mice. J Neurosci 20(20):7691-7697

75. Lee JK, Geoffroy CG, Chan AF, Tolentino KE, Crawford MJ, Leal MA, Kang B, Zheng B (2010) Assessing spinal axon regeneration and sprouting in Nogo-, MAG-, and OMgp-deficient mice. Neuron 66(5):663-670. doi:10.1016/j.neuron.2010.05.002

76. Masliah E, Xie F, Dayan S, Rockenstein E, Mante M, Adame A, Patrick CM, Chan AF, Zheng B (2010) Genetic deletion of Nogo/ Rtn4 ameliorates behavioral and neuropathological outcomes in amyloid precursor protein transgenic mice. Neuroscience 169(1):488-494. doi:10.1016/j.neuroscience.2010.04.045

77. Winzeler AM, Mandemakers WJ, Sun MZ, Stafford M, Phillips CT, Barres BA (2011) The lipid sulfatide is a novel myelinassociated inhibitor of CNS axon outgrowth. J Neurosci 31(17):6481-6492. doi:10.1523/JNEUROSCI.3004-10201131/ $17 / 6481$ pii

78. Stiles TL, Dickendesher TL, Gaultier A, Fernandez-Castaneda A, Mantuano E, Giger RJ, Gonias SL (2013) LDL receptor-related protein-1 is a sialic-acid-independent receptor for myelin-associated glycoprotein that functions in neurite outgrowth inhibition by MAG and CNS myelin. J Cell Sci 126(Pt 1):209-220. doi:10. $1242 /$ jcs. 113191

79. Huang ZH, Wang Y, Cao L, Su ZD, Zhu YL, Chen YZ, Yuan XB, He C (2008) Migratory properties of cultured olfactory ensheathing cells by single-cell migration assay. Cell Res 18(4):479-490. doi:10.1038/cr.2008.38

80. Fan Z, Shen Y, Zhang F, Zuo B, Lu Q, Wu P, Xie Z, Dong Q, Zhang H (2013) Control of olfactory ensheathing cell behaviors by electrospun silk fibroin fibers. Cell Transplant 22(Suppl 1):S39-S50. doi:10.3727/096368913X672190

81. Zhang LL, Huang LH, Zhang ZX, Hao DJ, He BR (2013) Compatibility of olfactory ensheathing cells with functionalized self-assembling peptide scaffold in vitro. Chin Med J (Engl) 126(20):3891-3896 